\title{
Role of vegetation in determining carbon sequestration along ecological succession in the southeastern United States
}

\section{Authors: Paul C. Stoy, Gabriel G. Katul, Mario B. S. Siqueira, Jehn-Yih Juang, Kimberly A. Novick, Heather R. McCarthy, A. Christopher Oishi, and Ram Oren}

This is the peer reviewed version of the following article: see citation below, which has been published in final form at https://doi.org/10.1111/j.1365-2486.2008.01587.x. This article may be used for non-commercial purposes in accordance with Wiley Terms and Conditions for SelfArchiving.

Stoy, Paul C., Gabriel G. Katul, Mario B. S. Siqueira, Jehn-Yih Juang, Kimberly A. Novick, Heather R. McCarthy, A. Christopher Oishi, and Ram Oren. "Role of Vegetation in Determining Carbon Sequestration Along Ecological Succession in the Southeastern United States." Global Change Biology 14, no. 6 (June 2008): 1409-1427. doi:10.1111/j.1365-2486.2008.01587.x. 


\title{
Role of vegetation in determining carbon sequestration along ecological succession in the southeastern United States
}

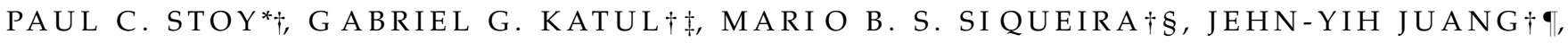 \\ KIMBERLY A. NOVICK†, HEATHER R. MCCARTHY $\dagger \|, A$. CHRISTOPHER OISHI† and \\ $\mathrm{RAM} \mathrm{OREN} \dagger$ \\ *Department of Atmospheric and Environmental Science, School of GeoSciences, University of Edinburgh, Edinburgh EH9 3JN, UK, \\ $\dagger$ Nicholas School of the Environment and Earth Sciences, Duke University, Box 90328, Durham, NC, USA, †Department of Civil \\ and Environmental Engineering, Pratt School of Engineering, Duke University, Durham, NC, USA, §Departamento de Engenharia \\ Mecânica, Universidade de Brasília, Brazil, -Department of Geography, National Taiwan University, Taipei, Taiwan, ||Department \\ of Earth System Science, University of California, Irvine, CA 92697-3100, USA
}

\begin{abstract}
Vegetation plays a central role in controlling terrestrial carbon (C) exchange, but quantifying its impacts on $\mathrm{C}$ cycling on time scales of ecological succession is hindered by a lack of long-term observations. The net ecosystem exchange of carbon (NEE) was measured for several years in adjacent ecosystems that represent distinct phases of ecological succession in the southeastern USA. The experiment was designed to isolate the role of vegetation - apart from climate and soils - in controlling biosphere-atmosphere fluxes of $\mathrm{CO}_{2}$ and water vapor. NEE was near zero over 5 years at an early successional old-field ecosystem (OF). However, mean annual NEE was nearly equal, approximately $-450 \mathrm{~g} \mathrm{C} \mathrm{m}^{-2} \mathrm{yr}^{-1}$, at an early successional planted pine forest (PP) and a late successional hardwood forest (HW) due to the sensitivity of the former to drought and ice storm damage. We hypothesize that these observations can be explained by the relationships between gross ecosystem productivity (GEP), ecosystem respiration (RE) and canopy conductance, and long-term shifts in ecosystem physiology in response to climate to maintain near-constant ecosystem-level water-use efficiency (EWUE). Data support our hypotheses, but future research should examine if GEP and RE are causally related or merely controlled by similar drivers. At successional time scales, GEP and RE observations generally followed predictions from E. P. Odum's 'Strategy of Ecosystem Development', with the surprising exception that the relationship between GEP and RE resulted in large NEE at the late successional HW. A practical consequence of this research suggests that plantation forestry may confer no net benefit over the conservation of mature forests for $\mathrm{C}$ sequestration.
\end{abstract}

Keywords: ecosystem respiration, ecological succession, eddy covariance, grass field, gross ecosystem productivity, net ecosystem exchange, oak-hickory forest, Pinus taeda

Introduction

North American terrestrial ecosystems represent a net C sink of debatable magnitude (Pacala et al., 2001; Potter et al., 2006), primarily attributable to forest growth and reforestation (Delcourt \& Harris, 1980; Caspersen et al., 2000) (but see Jackson et al., 2002), with strong inter- annual variability (Keeling et al., 1996; Fan et al., 1998; Houghton, 2000) due largely to changes in climate (Houghton, 2000). Plot-level studies (Delcourt \& Harris, 1980; Caspersen et al., 2000) and modeling approaches (Pacala et al., 2001; Potter et al., 2006) agree that the warm and moist southeastern (SE) region represents the strongest regional $\mathrm{C}$ sink in the USA.

Active land management (Wear \& Greis, 2002) and pronounced interannual climatic variability (Peters et al., 2003) make SE ecosystems ideal case studies for 
quantifying the role of physical and biological factors in controlling C sequestration. The SE comprises primarily private land and is thus subject to dramatic shifts in land use that correspond to both economic and natural forces (Wear \& Greis, 2002). Large-scale abandonment of agriculture after the US Civil War has continued to the present, and these old-field ecosystems have been largely replaced by forested ecosystems through ecological succession (Oosting, 1942; Johnston \& Odum, 1956). Since the 1950s, both abandoned agricultural ecosystems and second-growth forests have been increasingly converted to intensive forest plantations, commonly composed of loblolly pine (Pinus taeda L.) or similar fast growing species (Wear \& Greis, 2002). The result is a patchwork of vegetative types that represent different stages of ecological succession. This situation provides an opportunity to isolate the role of vegetation from that of climate and soils in controlling $\mathrm{C}$ flux in terrestrial ecosystems, and thus address one of the major research goals of the United States Global Change Research Program (USGCRP; Sarmiento \& Wofsy, 1999).

We quantified net ecosystem exchange of carbon (NEE) and its components, gross ecosystem productivity (GEP) and ecosystem respiration (RE), using longterm eddy-covariance measurements from old-field $(\mathrm{OF})$, planted pine (PP), and hardwood forest (HW) ecosystems that represent distinct stages of ecological succession in the SE. The ecosystems are adjacent and share identical macroclimatic conditions, and identical soil type over much of their extent, such that any difference in observed biosphere-atmosphere flux is largely due to the role of vegetation (Stoy et al., 2006a). The experimental setup was designed to examine ecological hypotheses regarding the roles of vegetation and climate in controlling long-term $\mathrm{C}$ exchange.

We examine three hypotheses pertinent to ecosystemscale processes:

(H1) At annual and growing season time scales, the variability in $R E$ is primarily explained by variability in GEP.

(H2) Changes in annual GEP $\left(\mathrm{GEP}_{\mathrm{A}}{ }^{1}\right)$ are primarily determined by differences in the magnitude of annual canopy conductance $\left(G_{c, A}\right)$ and its sensitivity to drought and disturbances.

(H3) After accounting for the effects of $G_{c}$ on GEP, the remaining variation in observed $\mathrm{GEP}_{\mathrm{A}}$ is attributable to changes in ecosystem physiology in response to climatic variability, namely the response of the ratio

\footnotetext{
${ }^{1}$ Throughout, flux variables with subscript A denote annual flux sums and the subscript GS denotes April-September peak growing season flux sums. The averaging operator \langle\rangle denotes annual or growing season averages.
}

of leaf-internal to atmospheric $\mathrm{CO}_{2}$ concentration (the $C_{\mathrm{i}} / C_{\mathrm{a}}$ ratio) to vapor pressure deficit $(D)$.

While current process-based models address some aspects of these three hypotheses, these models are known to fail in situations of drought or rapid disturbances, as evidenced by recent modeling studies focused on SE forested ecosystems (Hanson et al., 2004; Siqueira et al., 2006). It is envisioned that examining ecological hypotheses regarding the interplay between hydrology and C dynamics in a controlled experimental setting over long time scales will ultimately lead to model improvements.

Some preliminary experimental evidence for $\mathrm{H} 1$ follows from recent studies demonstrating that GEP and RE are strongly coupled (Högberg et al., 2001; Ryan \& Law, 2005) and also controlled by similar drivers (Reichstein et al., 2007). With respect to $\mathrm{H} 2$, it is well understood that leaf-level photosynthesis is fundamentally coupled to water fluxes via leaf stomatal function. However, models of canopy-level photosynthesis are complicated by vertical gradients in intercellular $\mathrm{CO}_{2}$ concentrations and shifts in leaf-level physiology due to canopy nitrogen distribution and temperature acclimation that interact with complex light environments (Kull \& Jarvis, 1995; Kull \& Kruijt, 1998, 1999; Gu et al., 2002). Also, ecosystem-level water fluxes comprise both transpiration and evaporation. Despite these complications, canopy-scale flux measurements permit the exploration of whether changes in $\mathrm{GEP}_{\mathrm{A}}$ are dominated by $G_{\mathrm{c}, \mathrm{A}}$ (Law et al., 2002). In addition to the strong role of hydrology via $G_{c}$ in controlling GEP (and thus potentially RE), Brodribb \& Feild (2000) and Katul et al. (2003) demonstrated that the parameters that determine canopy photosynthesis may themselves vary with hydrologic changes over longer time scales, which is examined in $\mathrm{H} 3$. The notion that $\mathrm{H} 2$ and $\mathrm{H} 3$ may interact such that their combined impact may be approximated by a nearconstant EWUE is also explored at interannual time scales. Hence, hydrology plays a central role in determining ecosystem $\mathrm{C}$ uptake via both canopy conductance at multiple time scales and physiological adjustments to climate at longer (e.g. seasonal and annual) time scales, the latter of which has received less attention.

We focus on relationships between measured ecosystem-level fluxes and climatic drivers that emerge to become important at longer time scales, namely the annual and growing season time scales, and reserve discussion of short-term dynamics for cases in which they contribute to the interpretation of $\mathrm{C}$ flux or ecological succession on longer time scales. The discussion of growing season time scales is intended to demonstrate that the results are robust at multiple time scales and 
insensitive to averaging over the wintertime period that generally has lower biological activity.

The measured flux results are discussed first in the context of the three hypotheses. We then place the results in the broader context of classic and contemporary ecological ideas regarding:

(E1) the role of assimilation and respiration in controlling the net $C$ flux of terrestrial ecosystems (Valentini et al., 2000; Reichstein et al., 2007);

(E2) $\mathrm{C}$ exchange along ecological succession, with a focus on the 'Strategy of Ecosystem Succession' of E. P. Odum (1969); and correspondingly

(E3) the role of ecosystem resistance and resilience to disturbances such as droughts and ice storms in maintaining the ecosystem service of $C$ sequestration.

\section{Methods}

\section{Site description}

The study ecosystems are located in the Blackwood Division of the Duke Forest near Durham, NC $\left(35^{\circ} 98^{\prime} \mathrm{N}, 79^{\circ} 8^{\prime} \mathrm{W}, 163 \mathrm{~m}\right.$ a.s.1.). The long-term (111-year) mean annual temperature is $15.5^{\circ} \mathrm{C}$ and long-term annual and April-September peak growing season precipitation is $1145 \pm 180$ and $632 \pm 130 \mathrm{~mm}$, respectively. Climate during the 1998-2005 measurement period was variable and included late-season droughts in 2001 and 2005 , a severe drought in 2002, a severe ice storm event in December 2002 (McCarthy et al., 2006), and wetter than average growing seasons in 1999, 2000, and 2003, with concomitant variability in photosynthetically active radiation (PAR) and D (Palmroth et al., 2005; Stoy et al., 2006a, b).

OF vegetation is harvested at least once a year and is dominated by the C3 grass Festuca arundinacea Schreb., with minor contributions from forbs and other $\mathrm{C} 3$ and C4 grass species (Novick et al., 2004). EC instrumentation is at $2.8 \mathrm{~m}$, and canopy height ranged from 0.1 to $1 \mathrm{~m}$ over the study period. PP is primarily composed of P. taeda L. with a diverse understory (Oren et al., 2001; Stoy et al., 2006a). Mean canopy height increased from $14 \mathrm{~m}$ in 1998 to $19 \mathrm{~m}$ in 2005 and EC instrumentation was raised from 15.5 to $20.2 \mathrm{~m}$ in January 2001. HW is an uneven-aged (80-100 years old) forest dominated by several Quercus (oak) and Carya (hickory) species (Pataki \& Oren, 2003; Palmroth et al., 2005; Stoy et al., 2005), with a minor component of evergreen species in the overstory (P. taeda) and understory (Juniperus virginiana L.). Canopy height averaged $25 \mathrm{~m}$ with some treetops exceeding $30 \mathrm{~m}$, and EC instrumentation is at $39.8 \mathrm{~m}$.

$\mathrm{OF}, \mathrm{PP}$, and HW are adjacent and flux towers lie within $750 \mathrm{~m}$ of each other such that their macroclimatic conditions are identical with minor seasonal differences in microclimate (e.g. $D$ ) due to vegetative activity (Stoy et al., 2006a). While rainfall, soil type, and rooting depth are similar across sites, soil moisture $(\theta)$ need not be identical among sites. For example, earlier spring drawdown of $\theta$ at PP compared with that at HW reflects differences in through-fall and transpiration, which is attributed to phenological differences between the two ecosystems (Stoy et al., 2005).

The dominant edaphic characteristics are similar among the adjacent ecosystems. All ecosystems lie on Enon silt loam, which transitions to Iredell gravelly loam in parts of OF and HW, and the soil profile of all ecosystems is dominated by a clay pan at a depth of ca. $30-50 \mathrm{~cm}$. Roots were not observed below $45 \mathrm{~cm}$ at OF (Lai \& Katul, 2000), and ET was well described by modeling root water capture in the upper $35 \mathrm{~cm}$ of soil. Likewise, water uptake in the upper $35 \mathrm{~cm}$ at PP balances sap flux-measured transpiration, and a clay pan was also observed at this depth (Oren et al., 1998). Stoy et al. (2006a) used the time series of soil moisture measurements to demonstrate that the effective rooting depth at HW is of the order $50 \mathrm{~cm}$, but direct soil core and pit measurements revealed few roots $(<1 \%$ by mass) below $35 \mathrm{~cm}$ in all ecosystems (K. Johnsen, unpublished data). Some edaphic differences among ecosystems cannot be ruled out (especially rooting depth), which may impact the results.

\section{Leaf area index measurements}

LAI at OF was estimated by calculating gap fractions from below-canopy PAR transmission measurements made using the 80 quantum sensor array on the AccuPAR PAR-80 Ceptometer (Decagon Instruments, Pullman, WA, USA). After 2001, LAI at OF was estimated by combining litterfall and LAI-2000 (Li-Cor, Lincoln, NE, USA) measurements. LAI at PP was calculated after McCarthy et al. (2007), who used a combination of needle elongation and litterfall measurements to measure the contribution of overstory $P$. taeda trees to total LAI, and a combination of degree-day sums and litterfall measurements to estimate LAI of the understory hardwood species. At HW, LAI was measured using a combination of LAI-2000 and litterfall measurements (Palmroth et al., 2005).

\section{Micrometeorological methodology}

Specific details regarding the EC and micrometeorological instrumentation at the OF, PP, and HW ecosystems can be found elsewhere (Katul et al., 2001; Novick et al., 2004; Stoy et al., 2006a). Briefly, fluxes were measured using open-path infrared gas analyzers (Li-Cor 7500) 
coupled with sonic anemometers (CSAT3, Campbell Scientific, Logan, UT, USA). A closed-path IRGA (LiCor 6262) was employed before May 1, 2001, at PP. Corrections to fluxes made using the closed path system are detailed in Oren et al. (2006). A full suite of micrometeorological measurements, including air temperature $\left(T_{\mathrm{a}}\right), D, \theta$, soil temperature, net radiation $\left(R_{\mathrm{n}}\right)$, and PAR, were made in conjunction with each EC system. The value of $\theta$ was intensively measured throughout the active rooting depth at all ecosystems using a combination of CS615 sensors (Campbell Scientific) and type ML1 ThetaProbe sensors (Delta-T Devices, Cambridge, UK).

A detailed analysis of the source weight function (used to compute the footprint) of EC-measured turbulent fluxes was performed to ensure that the flux source area did not exceed ecosystem dimensions or receive contamination from the nearby elevated $\mathrm{CO}_{2}$ rings of the Duke Forest FACE experiment at PP, or the privateland clear cut that occurred in December 2002, ca. $200 \mathrm{~m}$ south of the HW tower (Stoy et al., 2006b). A semianalytical footprint model originally developed by Hsieh et al. (2000) and extended to two dimensions by Detto et al. (2006) was used to quantify the dimensions of the flux footprint for half-hourly periods.

It is necessary to estimate transpiration $(T)$ and thereby $G_{\mathrm{c}}$ (through unit conversion and measured $D$ ) for the present analysis, which seeks to describe EC-measured fluxes in an ecological and hydrological context. We followed the approach of Stoy et al. (2006a,b), who found a relationship between modeled below-canopy radiation (Campbell \& Norman, 1998) and soil evaporation $(E)$. In this approach, measured ET during periods when the canopies were inactive [i.e. during leaf off at $\mathrm{OF}$ and $\mathrm{HW}$ and when $T_{\mathrm{a}}$ was below $10{ }^{\circ} \mathrm{C}$ at $\mathrm{PP}$ (Schäfer et al., 2002)] and not wet were identified and related to modeled forest floor radiation. This relationship was applied during all periods to produce a time series of $E$ estimates. $T$ and $G_{c}$ were then estimated by difference. These EC-based estimates of $T$ (500$560 \mathrm{~mm} \mathrm{yr}^{-1}$ for 2001-2004 excluding severe drought) closely matched sap flux estimates from $\mathrm{PP}$, which ranged from 520 to $530 \mathrm{~mm} \mathrm{yr}^{-1}$ (Schäfer et al., 2002; Stoy et al., 2006a).

\section{Calibration strategy}

A three-stage calibration procedure was adopted to ensure that the flux measurements were accurate and the flux sums are defensible. The calibration parameters of all three Li-Cor 7500 instruments were found to be stable over time, and each was calibrated biannually with minimal change in calibration coefficients $(<3 \%$ in all cases). The EC measurement systems at PP and HW were shown to be in good agreement with the Ameriflux roving system. To ensure that long-term flux sums are defensible, EC-measured $\mathrm{CO}_{2}$ flux time series were compared with against available independent measurements and model results from $\mathrm{C}$ budgeting approaches (Hamilton et al., 2002), inverse models (Lai et al., 2002b; Juang et al., 2006), physiology-based forward models (Luo et al., 2001), chamber respiration measurements (Palmroth et al., 2005), and constraints on assimilation based on sap flux and evapotranspiration (ET) measurements (Pataki \& Oren, 2003; Schäfer et al., 2003; Stoy et al., 2006a), as described by Stoy et al. (2006b). This comparison was performed to minimize and identify potential sources of error and bias in the estimation of NEE, GEP, and RE. The nonrectangular hyperbolic (NRH) method (Gilmanov et al., 2003) resulted in the best 'defensible' EC-based GEP and RE estimates after employing an atmospheric stability filter to remove nighttime measurements taken under conditions of insufficient turbulence (Novick et al., 2004; Stoy et al., 2006b). As discussed in Cava et al. (2004), very stable nocturnal conditions decouple the local flux measurements above the canopy from the $\mathrm{CO}_{2}$ production inside the canopy volume. It should be noted that harvesting removes ca. $200 \mathrm{~g} \mathrm{C} \mathrm{m}^{-2} \mathrm{yr}^{-1}$ on an average from $\mathrm{OF}$, and that the disagreement between $\mathrm{EC}$ and harvesting measurements likely represents EC-measurement uncertainty rather than other losses of $C$ from the ecosystem, for example via the export of dissolved organic $\mathrm{C}$ rather than chronic soil C loss. Jaksic et al. (2006) found that the uncertainty and interannual variability of NEE in a grassland ecosystem were of similar magnitude.

\section{Flux error}

The present analysis does not focus on errors in measured fluxes, as a full discussion of these errors has been presented elsewhere (Oren et al., 2006; Stoy et al., $2006 a, b)$. However, previous findings are reviewed for completeness. Error in $\mathrm{NEE}_{\mathrm{A}}$ at PP estimated after Goulden et al. (1996) varied between 79 and $127 \mathrm{~g} \mathrm{C} \mathrm{m}^{-2} \mathrm{yr}^{-1}$, due largely to uncertainty in gapfilling missing data (47-93\% of estimated error) and spatial variability in fluxes (6-49\%) rather than instrument error (1-6\%; Oren et al., 2006). Error values represent 1 $\mathrm{SD}$ about the estimated mean annual NEE. $\mathrm{NEE}_{\mathrm{A}}$ error ranged from 42 to $68 \mathrm{~g} \mathrm{C} \mathrm{m}^{-2} \mathrm{yr}^{-1}$ at $\mathrm{OF}$ and between 84 and $113 \mathrm{~g} \mathrm{CO}_{2} \mathrm{~m}^{-2} \mathrm{yr}^{-1}$ at HW (Stoy et al., 2006b). Error in $\mathrm{GEP}_{\mathrm{A}}$ and $\mathrm{RE}_{\mathrm{A}}$ was of the order of $9-30 \%$ and averaged $16 \%$ for the study period at all ecosystems (Stoy et al., 2006b). Missing data comprised 41\%, 43\%, and $40 \%$ of the OF, PP, and HW time series, respectively, somewhat higher than many other eddy-covariance 
sites (Falge et al., 2001), in accordance with our strict nighttime data filter (Novick et al., 2004). $\mathrm{ET}_{\mathrm{A}}$ estimates contained instrument and gapfilling error of the order of $7-14 \%$ for all ecosystems (Stoy et al., 2006a).

We note that the 30-min sum of sensible and latent heat fluxes explained $66-75 \%$ of the measured $R_{\mathrm{n}}$ at the three sites (Stoy et al., 2006a). It was shown by Stoy et al. (2006a) that the daily energy balance was nearly closed during days dominated by near-neutral atmospheric stability, while the largest average imbalance was observed during days dominated by near-convective conditions. This implies that the 30-min flux-averaging period may be adequate for near-neutral conditions, but appears to be filtering out nontrivial contributions of low-frequency eddies, the length scales of which are comparable to the (deep) convective atmospheric boundary layer height. This low-frequency loss under near-convective conditions may be by far more severe for sensible heat flux, rather than latent heat flux, because entrainment fluxes at the capping inversion can be as large as $30 \%$ of the surface sensible heat fluxes (Kim \& Entekhabi, 1998; Juang et al., 2007), and it is these entrainment fluxes that may be sampled under convective conditions. The broad agreement between ecosystem water balance studies and flux results at PP lends support to the notion that latent heat fluxes are not underestimated (Schäfer et al., 2002; Stoy et al., 2006a).

We additionally note that the EC system measures the turbulent flux crossing a horizontal plane above the given ecosystem, and internal recycling of $\mathrm{C}$ below the sensors cannot be measured. Some authors consequently prefer that ecosystem $C$ uptake be called GEP rather than GPP (Goulden et al., 1997; Stoy et al., 2006b). The differences between these two terms are likely to be minor, and we assume that GEP and GPP are comparable as per the FluxNet convention. These two terms are, thus, used interchangeably here.

\section{Analysis}

One of the goals of the present study is to analyze the coupled dynamics of carbon and water fluxes to address $\mathrm{H} 2$ and H3. To link the two fluxes mechanistically, we used Fick's law of diffusion:

$$
\mathrm{GEP}=\varepsilon G_{\mathrm{c}} C_{\mathrm{a}}\left(1-\frac{C_{\mathrm{i}}}{C_{\mathrm{a}}}\right),
$$

where $C_{\mathrm{a}}$ is the atmospheric $\mathrm{CO}_{2}$ concentration, $\varepsilon$ $(\sim 0.625)$ corrects for the difference in molecular diffusivity between $\mathrm{H}_{2} \mathrm{O}$ and $\mathrm{CO}_{2}$, and $\mathrm{C}_{\mathrm{i}} / \mathrm{C}_{\mathrm{a}}$ is the ratio of internal to external $\left[\mathrm{CO}_{2}\right]$ at the canopy scale and represents the 'driving force' for canopy $\mathrm{C}$ uptake.
Defining \langle\rangle as the annual or seasonal averaging operator, Eqn (1) can be used to explore mean annual GEP via

$$
\langle\mathrm{GEP}\rangle \approx \varepsilon C_{\mathrm{a}}\left[\left\langle G_{\mathrm{c}}\right\rangle\left(1-\left\langle\frac{C_{\mathrm{i}}}{C_{\mathrm{a}}}\right\rangle\right)\right] .
$$

We also investigate the April-September peak growing season period to demonstrate that the analysis is robust at multiple time scales. Note that the approximation in the above formulation is due to the fact that $\left\langle G_{\mathrm{c}} C_{\mathrm{i}} / C_{\mathrm{a}}\right\rangle=\left\langle G_{\mathrm{c}}\right\rangle\left\langle C_{\mathrm{i}} / C_{\mathrm{a}}\right\rangle+r_{G_{\mathrm{c}}, C_{\mathrm{i}} / C_{\mathrm{a}}} \sigma_{G_{\mathrm{c}}} \sigma_{C_{\mathrm{i}} / C_{\mathrm{a}}}$ and not $\left\langle G_{\mathrm{c}}\right\rangle\left\langle C_{\mathrm{i}} / C_{\mathrm{a}}\right\rangle$, where $r_{G_{c}, C_{\mathrm{i}} / C_{\mathrm{a}}}$ is the correlation coefficient between $G_{\mathrm{c}}$ and $C_{\mathrm{i}} / C_{\mathrm{a}}$, and $\sigma_{x}$ is the standard deviation of an arbitrary variable $x$. Katul et al. (2000) used a linearized analysis of the Farquhar et al. (1980) photosynthesis model to demonstrate that $\left|\frac{r_{C_{c}, C_{i} / C_{a}} \sigma_{G_{c}} \sigma_{C_{\mathrm{i}} / C_{a}}}{\left\langle G_{c}\right\rangle\left\langle C_{\mathrm{i}} / C_{\mathrm{a}}\right\rangle}\right| \ll 1$ when $\left\langle G_{\mathrm{c}}\right\rangle \neq 0$. We used $G_{\mathrm{c}}$ and $C_{\mathrm{i}} / C_{\mathrm{a}}$ estimates from Eqn (1) to determine that the value of $\frac{r_{G_{c}, C_{i} / C_{a}} \sigma_{G_{c}} \sigma_{C_{i}} / C_{a}}{\left\langle G_{c}\right\rangle\left\langle C_{\mathrm{c}} / C_{a}\right\rangle}$ is less than 0.015 for all ecosystems at the annual time scale. Hence, the observed variation in $\mathrm{GEP}_{\mathrm{A}}$ (or $\mathrm{GEP}_{\mathrm{GS}}$ ) can be decomposed into the product of variation in both $G_{\mathrm{c}, \mathrm{A}}$ and $C_{\mathrm{i}} / C_{\mathrm{a}, \mathrm{A}}$ (or corresponding growing season averages) with minimal error, noting also that annual $C_{\mathrm{a}}$ was relatively invariant over the 5-8-year periods analyzed here.

Combining Eqn (1) with the Fick's law analogy for $T$ ( $=\lambda G_{\mathrm{c}} D$, where $\lambda$ is a unit conversion factor) gives an ecosystem-scale approximation of water-use efficiency (EWUE):

$$
\mathrm{EWUE}_{\mathrm{A}} \approx \frac{\mathrm{GEP}_{\mathrm{A}}}{T_{\mathrm{A}}}=\frac{\varepsilon C_{\mathrm{a}}\left(1-\left\langle C_{\mathrm{i}} / C_{\mathrm{a}}\right\rangle\right)}{\lambda\langle D\rangle},
$$

which upon re-arranging yields

$$
\left\langle C_{\mathrm{i}} / C_{\mathrm{a}}\right\rangle_{\mathrm{A}} \approx 1-\left(\frac{\lambda}{\varepsilon C_{\mathrm{a}}} \operatorname{EWUE}_{\mathrm{A}}\right)\langle D\rangle .
$$

Growing season estimates for these variables are obtainable by substituting growing season sums or averages.

We also analyze a temporally averaged model for $G_{c, A}$ after Oren et al. (1999):

$$
\mathrm{G}_{\mathrm{c}, \mathrm{A}}=g_{\mathrm{s}, \mathrm{A}}\langle\mathrm{LAI}\rangle=\langle a\rangle\langle\mathrm{PAR}\rangle(1-m \ln \langle D\rangle)\langle\mathrm{LAI}\rangle,
$$

where the stomatal sensitivity parameter $m$ takes the theoretical value of 0.6 (Oren et al., 1999). We use this model to interpret changes in $G_{\mathrm{c}}$ in the analysis of $\mathrm{H} 2$ and $\mathrm{H} 3$.

\section{Results}

The major results of the long-term EC measurements are described first, followed by a presentation of results that relate to the experimental hypotheses, namely the relationships between GEP and RE and between $G_{c}$ and 
GEP, and the role of parameter variability in maintaining a near-constant EWUE.

At $\mathrm{OF}, \mathrm{GEP}_{\mathrm{A}}$ and $\mathrm{RE}_{\mathrm{A}}$ were nearly in balance, producing a near-zero mean $\mathrm{NEE}_{\mathrm{A}}$ (Table 1, Figs 1-3). However, it is important to note that adding the ca. $200 \mathrm{~g} \mathrm{C} \mathrm{m}^{-2} \mathrm{yr}^{-1}$ removed by harvesting results in an imbalance that likely represents flux uncertainty as discussed in Methods. Although mean $\mathrm{NEE}_{\mathrm{A}}$ at PP and $\mathrm{HW}$ were almost identical (ca. $-450 \mathrm{~g} \mathrm{C} \mathrm{m}^{-2} \mathrm{yr}^{-1}$ ), the variability (SD) in $\mathrm{NEE}_{\mathrm{A}}$ at PP was nearly fourfold that of $\mathrm{HW}$ due to large interannual variations in both GEP and RE (Figs 1-3). The magnitude of $\mathrm{NEE}_{\mathrm{A}}$ at PP was over twofold less during severe drought (2002) and immediately following the ice storm (2003) than its maximum of over $-600 \mathrm{~g} \mathrm{C} \mathrm{m}^{-2} \mathrm{yr}^{-1}$, which occurred during the 2 years with late-season droughts (2001 and 2005) (Figs 1 and 2).

OF was a source of $C$ to the atmosphere during the peak of the severe droughts of 2002 and 2005 (Figs 1 and 2). However, NEE switched sign rapidly after droughtbreaking rains (indicated by the stars in Fig. 2; see Fig. 2a in Stoy et al., 2006a for monthly precipitation time series) such that $\mathrm{NEE}_{\mathrm{A}}$ at $\mathrm{OF}$ remained near zero as a result. In contrast, the magnitude of $\mathrm{NEE}_{\mathrm{A}}$ at PP decreased dramatically in response to the severe drought from $-610 \mathrm{~g} \mathrm{C} \mathrm{m}^{-2} \mathrm{yr}^{-1}$ in 2001 to $-270 \mathrm{~g} \mathrm{C} \mathrm{m}^{-2} \mathrm{yr}^{-1}$ in 2002 (Figs 1 and 2). The magnitude of NEE remained low in 2003 due to the impacts of the December 2002 ice storm, and then took 2 years to recover to its previous maximum. This sequential decrease and increase in the magnitude of NEE is tracked by arrows in Fig. 2. NEE at HW was relatively resistant to the wide range of climatic variability observed.

When the annual mean and annual variability of GEP and RE are plotted against ecosystem age, the general shape of the relationship is similar to that given by Odum (1969) (Fig. 3), but $\mathrm{NEE}_{\mathrm{A}}$ did not approach zero in our case because of the significant relationship between $\mathrm{RE}_{\mathrm{A}}$ and $\mathrm{GEP}_{\mathrm{A}}$ for all site-years of flux data

Table 1 The mean and variability (SD in parentheses) of the annual net ecosystem exchange of $\mathrm{CO}_{2}$ (NEE) and its components - gross ecosystem productivity (GEP) and ecosystem respiration (RE) at old-field (OF), planted pine (PP) and hardwood forest (HW) ecosystems in the Duke Forest, NC

\begin{tabular}{lllll}
\hline Ecosystem & NEE & GEP & RE & GEP/RE \\
\hline OF & $10(40)$ & $-1230(210)$ & $1240(230)$ & $-0.99(0.03)$ \\
PP & $-460(190)$ & $-1890(390)$ & $1440(340)$ & $-1.33(0.15)$ \\
HW & $-440(50)$ & $-1710(30)$ & $1260(50)$ & $-1.35(0.05)$ \\
\hline
\end{tabular}

Signs follow the micrometeorological convention where flux from atmosphere to biosphere is denoted as negative. Flux units are in $\mathrm{gC} \mathrm{m}^{-2} \mathrm{yr}^{-1}$.
$(P<0.0002) . \mathrm{RE}_{\mathrm{A}}$ was significantly related to $\mathrm{GEP}_{\mathrm{A}}$ at OF and PP $(P<0.005)$, and this pattern also held at the growing season time scale $(P<0.02)$. The relatively invariant annual and growing season fluxes at HW failed to produce a strong relationship. Using monthly averages, GEP explained $84 \%$ of the variation in RE at $\mathrm{OF}, 71 \%$ at PP, and $63 \%$ at HW (Fig. 4). Both linear and exponential models using monthly average $T_{\mathrm{a}}$ or soil temperature explained a lesser amount of the RE variation, ca. $68 \%, 50 \%$, and $56 \%$ for the case of $T_{\mathrm{a}}$ at the three ecosystems, respectively.

$\mathrm{GEP}_{\mathrm{A}}$, not $\mathrm{RE}_{\mathrm{A}}$, was significantly related to $\mathrm{NEE}_{\mathrm{A}}$ after pooling measurement years from all ecosystems $(P<0.001)$, and this relationship also held at the growing season time scale. However, $\mathrm{RE}_{\mathrm{A}}$ explained a larger degree of the variability in $\mathrm{NEE}_{\mathrm{A}}$ at $\mathrm{HW}\left(r^{2}=0.6\right)$ than $\operatorname{did} \mathrm{GEP}_{\mathrm{A}}\left(r^{2}=0.1\right)$. The relationship between $\mathrm{RE}_{\mathrm{GS}}$ and $\mathrm{NEE}_{\mathrm{GS}}$ at $\mathrm{HW}$ was significant $\left(r^{2}=0.94 ; P=0.0071\right)$ as opposed to the relationship between $\mathrm{GEP}_{\mathrm{GS}}$ and $\mathrm{NEE}_{\mathrm{GS}}$ at $\mathrm{HW}(P=0.83)$. We note that these relationships are a secondary issue given the small variations in $\mathrm{NEE}_{\mathrm{A}}$ at $\mathrm{HW}$ and the uncertainty in gap-filled $\mathrm{RE}_{\mathrm{A}}$.

$\mathrm{GEP}_{\mathrm{A}}$ and $\mathrm{GEP}_{\mathrm{GS}}$ were closely related to $T$ and thereby $G_{\mathrm{c}}{ }^{2}$ at $\mathrm{OF}\left(\mathrm{A}: r^{2}=0.77, P=0.048 ; \mathrm{GS}: r^{2}=0.85\right.$, $P=0.025)$ and PP (A: $r^{2}=0.62, P=0.021$; GS: $r^{2}=0.84$, $P=0.012)$, but not HW (A: $r^{2}=0.0046, P=0.91$; GS: $r^{2}=0.53, P=0.16$ ) (Fig. 5). Again, the weak correlation at $\mathrm{HW}$ is primarily due to the small interannual variability of $\mathrm{GEP}_{\mathrm{A}}$ and $G_{\mathrm{c}, \mathrm{A}}$.

Guided by various leaf-level studies including Leuning (1995), Farquhar et al. (1993), Lloyd \& Farquhar (1994), Cowan \& Farquhar (1977), and Wong \& Dunin (1987), the notion that ecosystem-level $C_{\mathrm{i}} / C_{\mathrm{a}}$ from Eqn (1) is related to mean annual and growing season $D$ at all ecosystems [Eqn (4)] is explored in Fig. 6 (A. OF: $r^{2}=0.59, \quad P=0.02 ; \quad$ PP: $\quad r^{2}=0.84, \quad P=0.001 ; \quad H W$ : $r^{2}=0.97, P=0.002 ;$ GS. OF: $r^{2}=0.60, P=0.12 ; \quad P P$ : $r^{2}=0.71, P=0.009$; HW: $\left.r^{2}=0.98, P=0.001\right)$. The linearity of this dependence (Fig. 6) has important implications to the near-constant EWUE, discussed later. In contrast to the strong relationships between $C_{i} / C_{a}$ and $D$ at all ecosystems and time scales (except the growing season time scale at $\mathrm{OF}$ ), well-known relationships between PAR and GEP and between $T_{\mathrm{a}}$ and RE were significant at short time scales using half-hourly data $(P<0.05)$, but not at the annual or growing season time scales $(P>0.05)$ for all ecosystems.

${ }^{2} G_{\mathrm{c}}$ (usually expressed in mol $\mathrm{m}^{-2}$ time $^{-1}$ ) can be converted to $T$ (usually expressed in $\mathrm{mm} \mathrm{time}^{-1}$ ) by considering the latent heat of vaporization and vapor pressure deficit, both functions of $T_{\mathrm{a}}$. Throughout, we use $G_{c}$ when referring to Eqn (1), and $T$ when referring to annual or seasonal canopy water flux. 


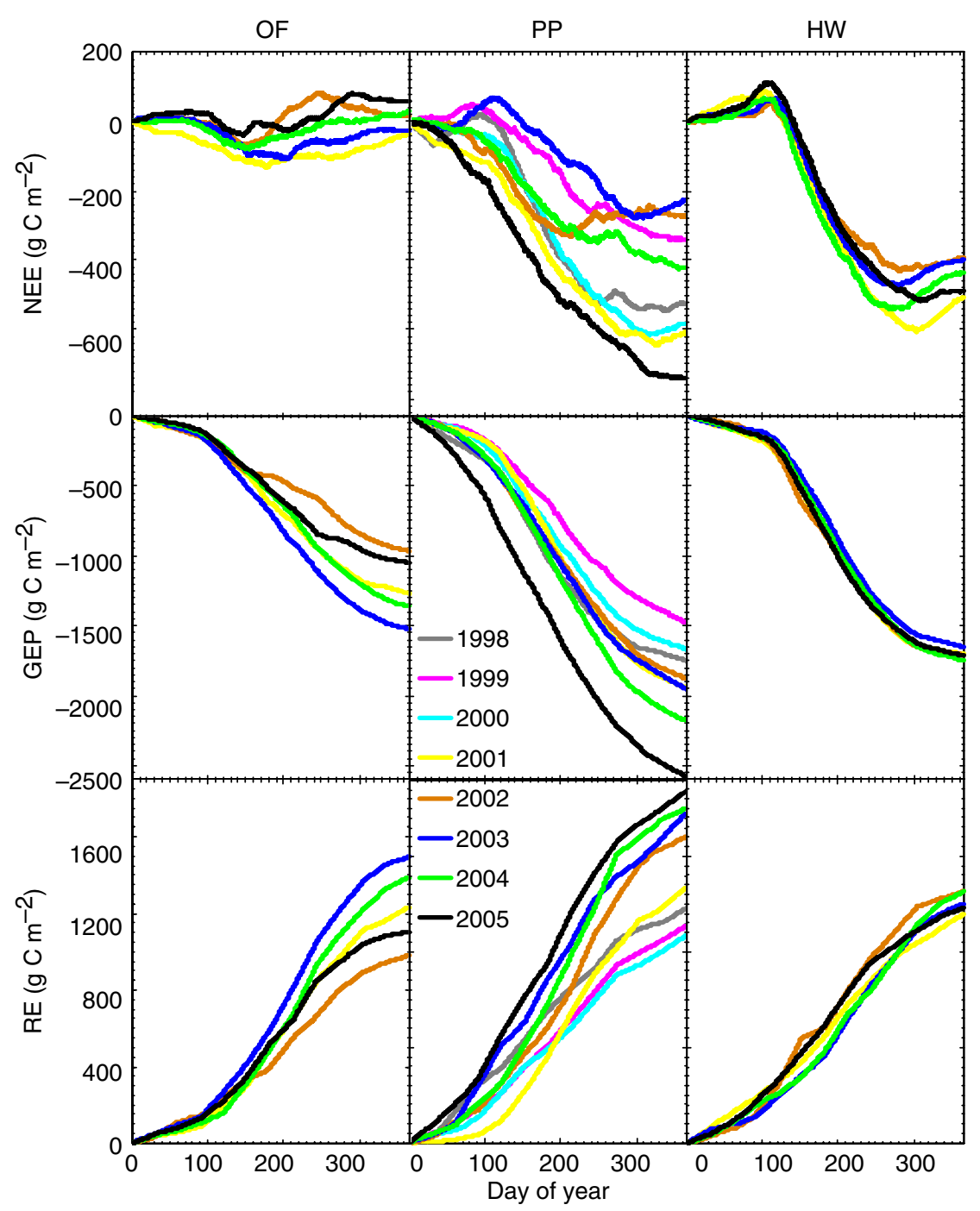

Fig. 1 Cumulative annual net ecosystem exchange of $\mathrm{CO}_{2}$ (NEE), gross ecosystem productivity (GEP), and ecosystem respiration (RE) at the adjacent old-field (OF), planted pine (PP), and broadleaf deciduous (HW) forests in the Duke Forest, NC. The measurement record began in 1998 at PP and in 2001 at OF and HW. Signs follow the micrometeorological convention where flux from atmosphere to biosphere is denoted as negative. Flux error is discussed in Oren et al. (2006) and Stoy et al. (2006a, b).

The parameters that describe $G_{c}$ [Eqn (5)] varied at the annual time scale in response to canopy structure and diffuse radiation. The mean annual (or growing season) light sensitivity of canopy conductance $(\langle a\rangle)$ increased with decreasing $\langle\mathrm{LAI}\rangle$ owing to less selfshading of the canopies (Fig. 7a and b; A: $r^{2}=0.85$, $P<0.001$; GS: $r^{2}=0.77, P<1.6 \times 10^{-6}$ ). $\langle a\rangle$ also increased with an increasing ratio of diffuse PAR in the forest ecosystems (Fig. 7c and d).

\section{Discussion}

The hypotheses are first discussed in the context of the experimental results. Next, the ecological implications of the experimental findings are explored via E1-E3, and their relevance to ecosystem management is also presented.

\section{Hypothesis 1: GEP is the primary determinant of RE}

In the ecosystems studied here and, importantly, at the time scales that we have measured, variability in RE at annual, growing season and monthly time scales appears to be more related to GEP than to total biomass (see Table 2 in Stoy et al., 2006a) or extant environmental drivers such as temperature (see also Law et al., 2002) that act upon the entire ecosystem $\mathrm{C}$ pool. This is despite the fact that most short-term RE models are 


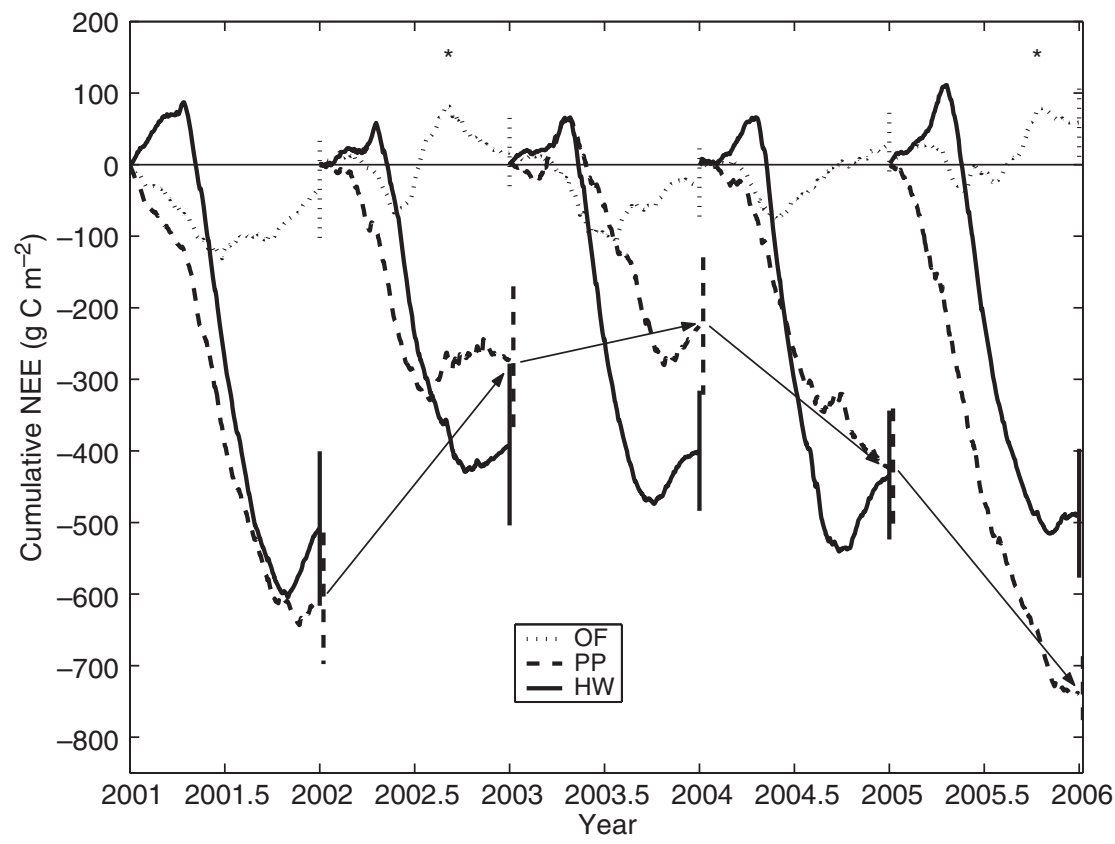

Fig. 2 Same as Fig. 1a-c, detailing differences in the cumulative sum of net ecosystem exchange of C (NEE) for each year during 20012005 , the period over which measurements were available at all three study ecosystems. Asterisks denote the timing of drought-breaking rains in 2002 and 2005. Arrows indicate changes in annual NEE at the planted pine (PP) ecosystem. Error bars indicate \pm 1 SD about the mean annual estimate calculated after Goulden et al. (1997) by Stoy et al. (2006b).

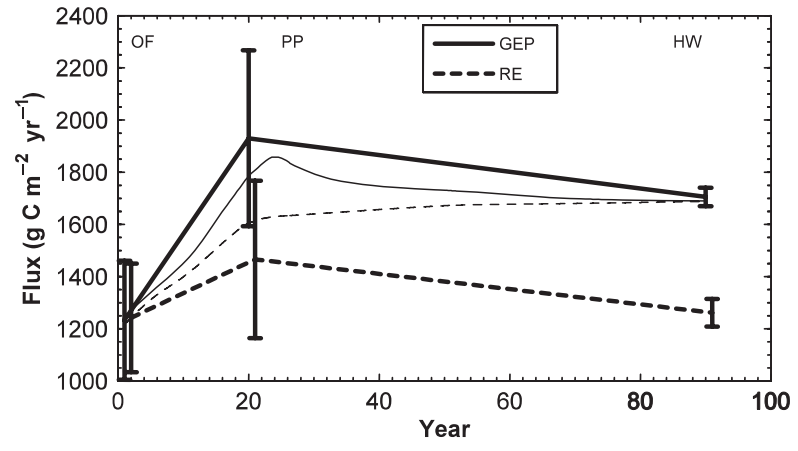

Fig. 3 Change in mean annual GEP and RE estimates (thick lines) from the initial condition (OF) to early successional (PP) and late successional (HW) forests with annual variability (standard deviation) denoted as error bars. The relationships of Odum are drawn for comparison in thin lines, noting that gross primary productivity (GPP) rather than GEP was used in the original study. The original figure did not reference an ordinate; Fig. 1a of Odum (1969) was digitized and scaled to approximately match the flux magnitude observed here. Years are approximate.

driven by temperature (Morgenstern et al., 2004), and temperature-driven models well describe daily $R_{\text {soil }}$ at PP and HW under conditions of adequate soil moisture (Palmroth et al., 2005). Although RE is likely to vary with ecosystem biomass, the variability in RE appears to be dominated by $\mathrm{C}$ pools with short turnover times rather than recalcitrant $C$ pools in the stem or soil (e.g. Taneva et al., 2006). Future work should disentangle the central or complementary role played by GEP in determining the magnitude of RE (Janssens et al., 2001; Ryan \& Law, 2005), and also investigate the temperature response of the different C pools (Bosatta \& Ågren, 1999), noting that labile $C$ pools from recent photoassimilates may dominate RE in many ecosystems (Davidson \& Janssens, 2006).

The results here conceptually agree with a number of recent studies that have quantified the importance of GEP to $R_{\text {soil }}$ (Högberg et al., 2001; Ekblad et al., 2005; Tang et al., 2005) and RE (Janssens et al., 2001). $R_{\text {soil }}$ dominates RE at HW and comprises a large proportion of RE at PP (Schäfer et al., 2003; Mortazavi et al., 2005; Palmroth et al., 2005). However, based on this analysis with eddy-covariance data, we cannot determine if GEP and RE are fundamentally coupled (H1), or if they simply co-vary, because they are controlled by similar environmental drivers (Reichstein et al., 2007). There is some indirect evidence for the former given that both $R_{\text {soil }}$ and RE at PP and HW show the isotopic signature of recently assimilated C (Andrews et al., 1999; Mortazavi et al., 2005), and some $70 \%$ of $R_{\text {soil }}$ at PP arises from pools with turnover times of 1 month or less (Taneva et al., 2006). However, Stoy et al. (2007) investigated the 


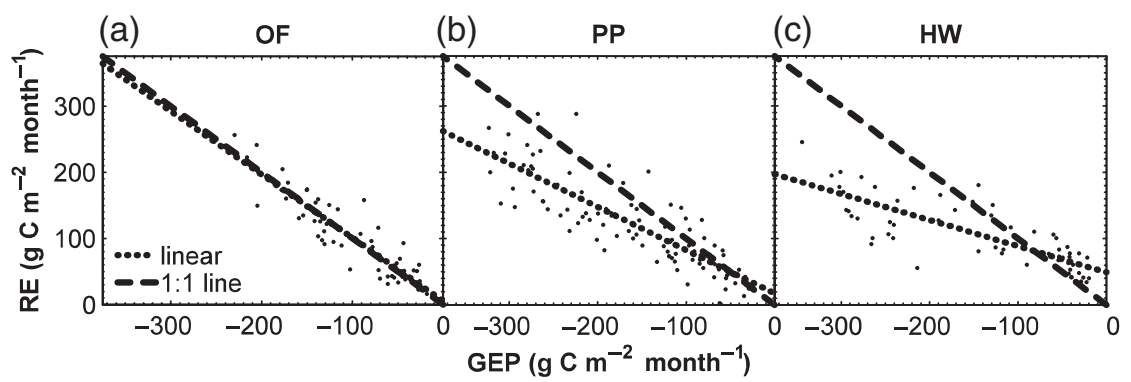

Fig. 4 Relationship between the monthly sums of gross ecosystem productivity (GEP) and ecosystem respiration (RE) at the three study ecosystems. OF, old-field; PP, planted pine forest; HW, hardwood forest ( $P \ll 0.05$ in all cases).
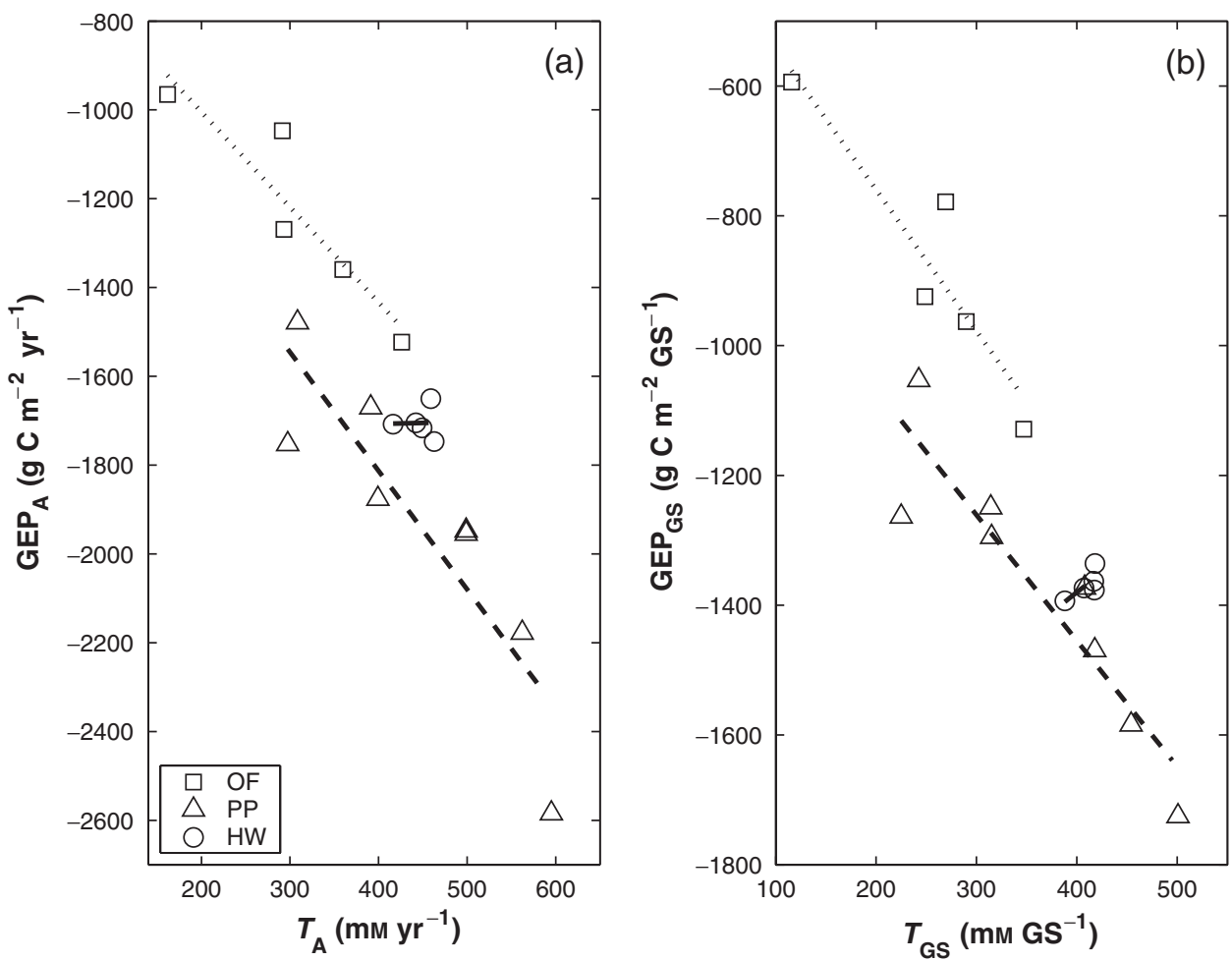

Fig. 5 (a) Relationship between annual transpiration $\left(T_{\mathrm{A}}\right)$ estimated using the radiation attenuation approach of Stoy et al. (2006b) and annual gross ecosystem productivity $\left(\mathrm{GEP}_{\mathrm{A}}\right)$ at the old-field $(\mathrm{OF})$, planted pine $(\mathrm{PP})$ and hardwood forest $(\mathrm{HW})$ study ecosystems. Error in GEP and T estimates is discussed elsewhere (Oren et al., 2006; Stoy et al., 2006a, b). (b) Same as part (a), but using April-September peak growing season (GS) sums (OF. A: $r^{2}=0.77, P=0.048$; GS: $r^{2}=0.85, P=0.025$. PP. A: $r^{2}=0.62, P=0.021 ; \mathrm{GS}: r^{2}=0.84, P=0.012$. HW. A: $\left.r^{2}=0.0046, P=0.91 ; \mathrm{GS}: r^{2}=0.53, P=0.16\right)$.

coupling between photosynthesis and soil respiration at relatively short time scales (of the order of days) at PP and HW and found little evidence of a strong coupling. It was argued that multiple turnover times in the labile $\mathrm{C}$ pool in both plant and soil obscured any obvious pulse-response dynamics between ecosystem $\mathrm{C}$ uptake and loss. Again, the important finding here is the strong correlation between GEP and RE, with respect to environmental drivers, at seasonal and annual time scales, although the precise causation remains to be explored.
Hypothesis 2: $\mathrm{G}_{c}$ is the primary determinant of GEP

Changes in $\mathrm{GEP}_{\mathrm{A}}$ are linearly related to differences in the magnitude of annual canopy conductance $\left(G_{c, A}\right)$ and its sensitivity to drought and disturbances (Fig. 5 ), as predicted by the mechanistic model for diffusive flux, Fick's law [Eqn (1)], irregardless of averaging via Eqn (2). Notwithstanding the small scatter for the HW site, it is interesting to note that the inverse of the slopes of the $\mathrm{GEP}_{\mathrm{A}} / T$ relationships for $\mathrm{OF}, \mathrm{PP}$, and $\mathrm{HW}$ were 

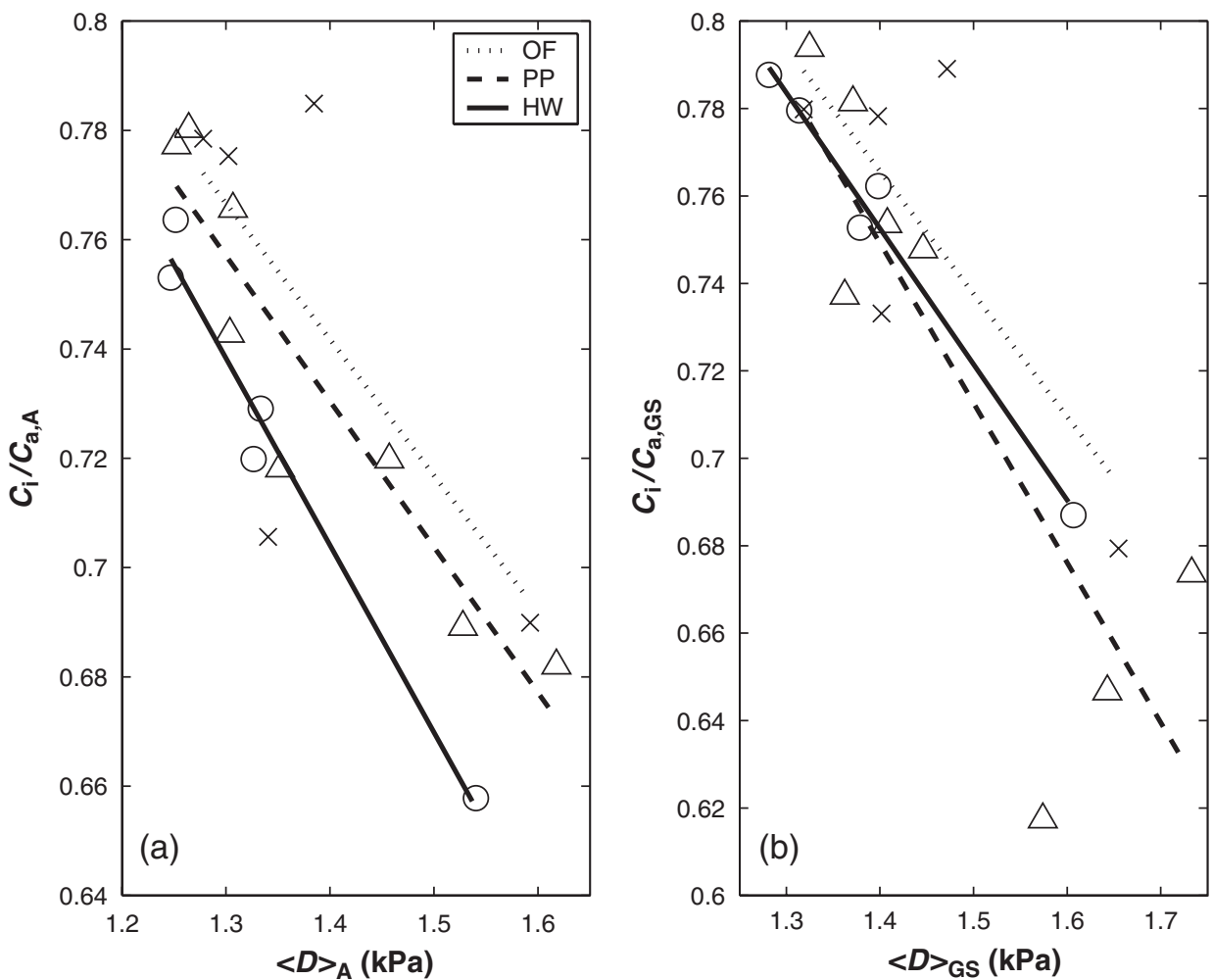

Fig. 6 (a) Relationship between mean annual vapor pressure deficit $\left(\langle D\rangle_{\mathrm{A}}\right)$ and the ratio of leaf-internal to atmospheric $\left[C \mathrm{O}_{2}\right]$ at the annual time scale $\left[C_{\mathrm{i}} / C_{\mathrm{a}, \mathrm{A}}\right.$, Eqn (1)] in the study ecosystems. OF, old-field (squares); PP, planted pine forest (triangles); HW, hardwood forest (circles). Note that for constant water-use efficiency, the relationship between $C_{\mathrm{i}} / C_{\mathrm{a}}$ and $D$ must be linear [Eqn (6)]. (b) Same as part (a), but using April-September peak growing season (GS) averages (OF. A: $r^{2}=0.59, P=0.02$; GS: $r^{2}=0.60, P=0.12$. PP. A: $r^{2}=0.84$, $P=0.001$; GS: $r^{2}=0.71, P=0.009$. HW. A: $r^{2}=0.97, P=0.002$; GS: $r^{2}=0.98, P=0.001$ ).

comparable (3.4, 3.8, and $3.8 \mathrm{~g} \mathrm{C} \mathrm{kg}^{-1} \mathrm{H}_{2} \mathrm{O}$, respectively), if we assume that $\mathrm{GEP}_{\mathrm{A}}$ is negligible for negligible $T$ (i.e. if a point at zero flux is included in the computation). These values are 3.2, 3.4, and $3.3 \mathrm{~g} \mathrm{C} \mathrm{kg}^{-1} \mathrm{H}_{2} \mathrm{O}$ for $\mathrm{OF}, \mathrm{PP}$, and $\mathrm{HW}$, respectively, at the growing season time scale and collectively suggest that the long-term ecosystem water-use efficiencies are comparable across the three ecosystems, in further support of $\mathrm{H} 2$ and $\mathrm{H} 3$.

\section{Hypothesis 3: parameter variability describes remaining variability in GEP}

The relationship between $C_{\mathrm{i}} / C_{\mathrm{a}}$ and $D$ [Eqn (4)] at short (e.g. half-hourly) time steps in $\mathrm{C} 3$ species has been demonstrated often (e.g. Leuning, 1995; Katul et al., 2000 ), and $D$ is known to be one of the most important explanatory variables for modeling weekly to monthly GEP at PP (Stoy et al., 2005). The approximately linear relationship between $\left\langle C_{\mathrm{i}} / C_{\mathrm{a}}\right\rangle$ and $\langle D\rangle$ at the annual and growing season time scales (Fig. 6) can be analyzed in the context of constant water-use efficiency for the different canopies.
One might expect $\left\langle C_{\mathrm{i}} / C_{\mathrm{a}}\right\rangle_{\mathrm{A}}$ to vary linearly as a function of $\langle D\rangle_{\mathrm{A}}$ (Fig. 6) if $\mathrm{EWUE}_{\mathrm{A}}$ is near constant, as already suggested by the slopes of Fig. 5 (H2). The $C_{\mathrm{i}} / C_{\mathrm{a}}$ ratio is related to canopy physiology in that it reflects the driving force for $C$ uptake from Eqn (1). Equation (4) demonstrates that canopy physiology responds linearly to atmospheric demand for water (i.e. $D)$ at longer time scales if EWUE is near constant. Note also that the slopes in Fig. 6 support the comparable EWUE found in Fig. 5 for PP and OF. When compared with the inverse of the slopes in Fig. 5, the analysis in Fig. 6 is perhaps more revealing about the constant EWUE $_{\mathrm{A}}$ for HW, because the spread in $\langle D\rangle_{\mathrm{A}}$ and $\langle D\rangle_{\mathrm{GS}}$ at the three ecosystems is now comparable. Interestingly, the analysis in Fig. 6 suggests that the $\mathrm{EWUE}_{\mathrm{A}}$ is approximately equal at all three ecosystems, but slightly larger at HW and PP at the annual and growing season time scales, respectively. In short, while many internal leaf-level physiological parameters for each of the three ecosystems are not stationary across years (e.g. Ellsworth, 1999), it appears that their cumulative impact may still be captured by a near-constant EWUE for this semidecadal time-scale analysis. Furthermore, the var- 

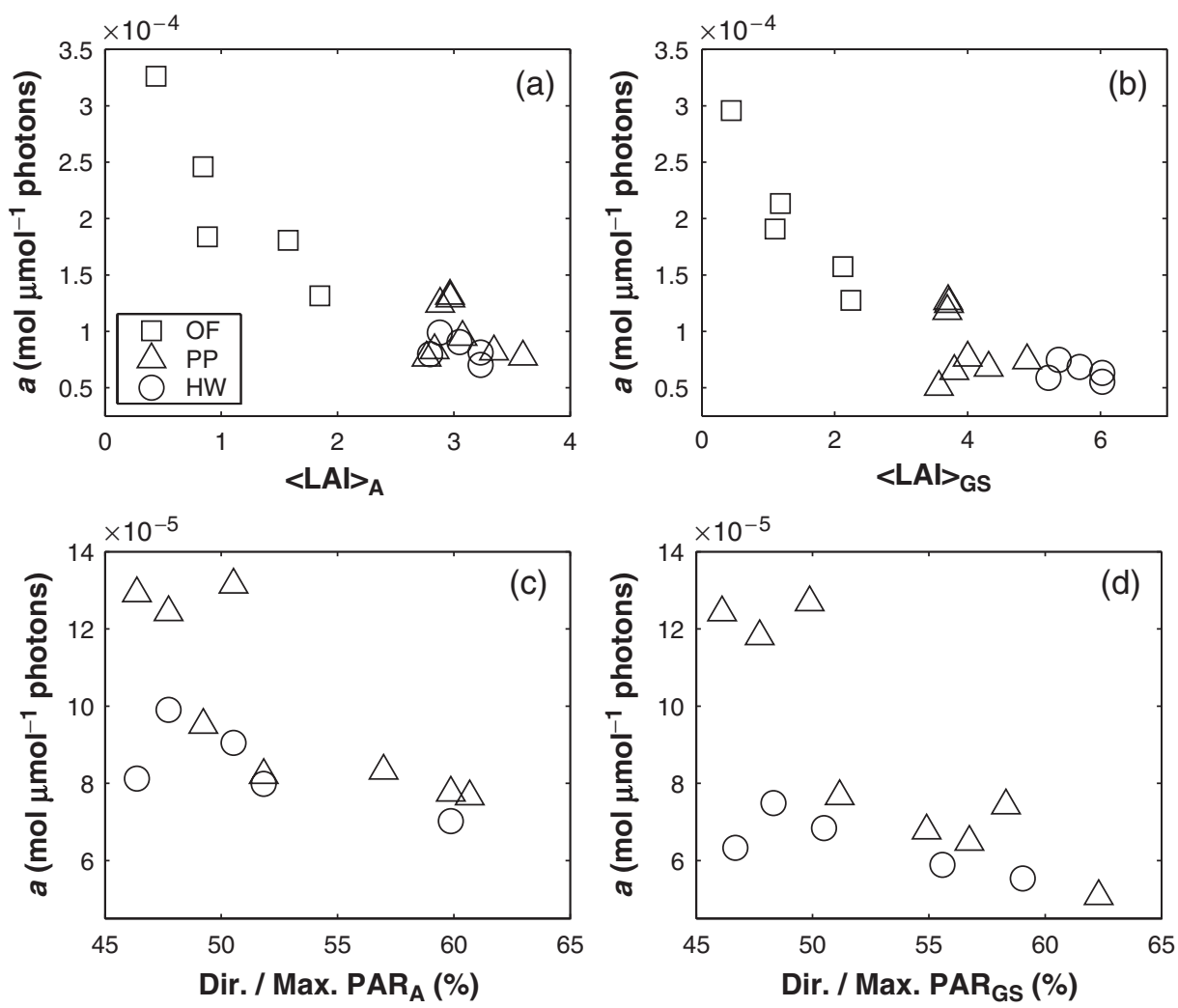

Fig. 7 (a) Relationship between the light sensitivity of canopy conductance at the annual time scale (a) to mean annual leaf area index $(\langle\mathrm{LAI}\rangle)$ at the old-field (OF), planted pine (PP), and hardwood forest (HW) ecosystems in the Duke Forest, NC. (b) Same as part (a), but for growing season (GS) averages (A: $r^{2}=0.85, P<0.001$; GS: $r^{2}=0.77, P<1.6 \times 10^{-6}$ ). The relationship between $\langle a\rangle_{\mathrm{A}}$ and the fraction of direct (Dir.) to maximum photosynthetically active radiation (PAR) at the annual (c) and April-September peak growing season (d) time scales (A: $r^{2}=0.39, P=0.022 ; \mathrm{GS}: r^{2}=0.40, P=0.020$ ).

iation of long-term EWUE across the three ecosystems is surprisingly small, perhaps suggesting that in a firstorder analysis, its bulk value is set by climate and soil type rather than ecosystem type.

This result also implies that simple mechanistic models for GEP may be obtained by combining Eqn (1) with mechanistic models for $G_{c}$ and the relationship between $C_{\mathrm{i}} / C_{\mathrm{a}}$ and $D$ (Leuning, 1995). Models that employ lightresponse curves for estimating GEP should ensure that both the short-term and long-term dynamics of GEP are accurately estimated, as we found no significant relationship between $\mathrm{PAR}_{\mathrm{A}}$ and $\mathrm{GEP}_{\mathrm{A}}$ (or $\mathrm{PAR}_{\mathrm{GS}}$ and $\mathrm{GEP}_{\mathrm{GS}}$ ) at our study ecosystems. It is important to reiterate that we also found no relationship between mean annual air and soil temperature and $\mathrm{RE}_{\mathrm{A}}$ (Janssens et al., 2001; Law et al., 2002), despite the widespread use of temperature-based respiration models (Morgenstern et al., 2004).

In addition to the case of $C_{\mathrm{i}} / C_{\mathrm{a}}$ and $D$, there are other examples in which ecosystem parameters vary with respect to climatic or biological conditions that have clear implications for ecological modeling. The para- meters that describe $G_{c}$ varied at the annual time scale in response to canopy structure and diffuse radiation [Eqn (5)]; the mean annual (or growing season) $\langle a\rangle$ increased with decreasing $\langle\mathrm{LAI}\rangle$ owing to less selfshading of the canopies (Fig. 7a and b) and an increasing ratio of diffuse PAR in the forest ecosystems (Fig. 7c and d), consistent with studies on whole-canopy response to diffuse radiation (Gu et al., 2002). Diffuse radiation can penetrate plant canopies more readily and has been shown both theoretically and experimentally to increase canopy photosynthesis over direct radiation (Gu et al., 1999, 2003; Law et al., 2002). Thus, long-term ecosystem responses to hydrology and radiation quality controlled annual C fluxes in the study ecosystems, rather than the responses to temperature and radiation quantity.

\section{E1: controls on NEE by component fluxes}

If GEP and RE are related (H1), the question becomes: how do they interact to determine the $\mathrm{C}$ balance along successional time scales? Results here provide a differ- 
ent picture than continental-scale studies of forested ecosystems, which suggest that variability in RE primarily controls the $\mathrm{C}$ balance across space (Valentini et al., 2000). Rather, because of the coupling between GEP and RE, the former may play a more important role in determining long-term $\mathrm{C}$ fluxes across different ecosystems (Janssens et al., 2001; Reichstein et al., 2007). Variability in $\mathrm{GEP}_{\mathrm{A}}$ was in general more related to variability in $\mathrm{NEE}_{\mathrm{A}}$ at $\mathrm{OF}$ and $\mathrm{PP}$, but $\mathrm{NEE}_{\mathrm{A}}$ was nearly constant at HW when compared with $\mathrm{OF}$ and $\mathrm{PP}$, making it difficult to discern the relative importance of its component fluxes in determining its variability. Taken as a whole, these results emphasize the relative importance of GEP over RE in determining the medium (monthly) and long-term (interannual) variability in NEE, despite the strong relationships between instantaneous (half-hourly) RE and temperature.

\section{E2: C exchange along succession}

$\mathrm{NEE}_{\mathrm{A}}$ at $\mathrm{OF}$ was near zero, $\mathrm{PP}$ was the most productive of the three ecosystems under ideal conditions, and $\mathrm{NEE}_{\mathrm{A}}$ at $\mathrm{HW}$ was highly resistant to climatic variability (Table 1, Figs 1-3). These results largely followed expectations based on the 'Strategy of Ecosystem Development' of Odum (1969), which hypothesizes that GPP rapidly increases with ecological succession, then decreases as forests age, while RE increases monotonically due to the increase in autotrophic biomass. There is an important difference between flux results and the 'Strategy of Ecosystem Development'; the covariance between GEP and RE (H1) resulted in a decrease in RE along the forest succession studied here such that mean $\mathrm{NEE}_{\mathrm{A}}$ at PP and HW was almost identical over the respective 8-year and 5-year measurement periods (Table 1), as well as the commonly measured 5-year period.

It is important to note that Odum's hypothesis was based on a single time series of temperate forest succession (Kira \& Shidei, 1967), as is the present study. Regardless, Odum's theory is conceptually appealing given its simplicity, and is often presented in textbooks (e.g. Odum, 1971; Schlesinger, 1997), leading generations of ecologists to acknowledge its basic tenets. Whereas our experimental evidence largely agrees with its assumptions, modifying these 'classic' ideas by acknowledging a covariance between GEP or RE (Högberg et al., 2001; Janssens et al., 2001; Ryan \& Law, 2005) may provide a realistic picture of $\mathrm{C}$ exchange along succession while retaining the simplicity of Odum's hypothesis, although this assertion must be tested using many and various examples of ecological succession. 'Modernizing' the 'Strategy of Ecosystem Development' (Odum, 1969) to take into account the relationship between GEP and RE may improve understanding of biosphere-atmosphere $C$ exchange over successionary time scales and, combining our results with others, may help dispel the prevailing idea that mature forest ecosystems with large $C$ pools must be small $C$ sinks (see Carey et al., 2001; Röser et al., 2002; Knohl et al., 2003; Zhou et al., 2006; Urbanski et al., 2007; Baldocchi, 2008).

\section{E3: ecological resistance and resilience}

Odum (1969) additionally hypothesized that early successional ecosystems maximize productivity, while late successional ecosystems maximize 'protection' against (i.e. resistance to) environmental variation. Indirect evidence of this characteristic can be identified in the NEE measurements: $\mathrm{NEE}_{\mathrm{A}}$ at PP was highest under ideal conditions, but was also highly variable in response to environmental variability, while the interannual variability of $\mathrm{NEE}_{\mathrm{A}}$ at $\mathrm{HW}$ was small (Table 1, Figs $1-3)$.

We can indirectly explore these ideas in the context of ecological resistance and resilience for the case of biosphere-atmosphere interaction (Moorcroft, 2003). A logical first step follows from examining the sensitivity of $C$ uptake to changes in $G_{c}$ after Eqn (1), which have been thoroughly quantified for the study ecosystems (Oren et al., 1998; Schäfer et al., 2002; Pataki \& Oren, 2003; Stoy et al., 2006a).

$\mathrm{GEP}_{\mathrm{A}}$ and $\mathrm{GEP}_{\mathrm{GS}}$ were strongly related to $G_{\mathrm{c}, \mathrm{A}}$ and $G_{c, G S}$, respectively (H2, Fig. 5), and the observed interannual changes in $G_{\mathrm{c}}$ are explainable by the sensitivity to and recovery from drought and disturbance (i.e. ecological resistance and resilience to perturbations) of canopy dominant species (Oren et al., 1998; Oren \& Pataki, 2001; Pataki \& Oren, 2003; Novick et al., 2004; Stoy et al., 2005, 2006a; Siqueira et al., 2006). Long-term changes in $G_{c, G s}$ at OF occurred via a decrease in LAI in response to drought and an increase in the intrinsic mean stomatal conductance $\left(g_{\mathrm{s}}\right)$ during wet years (Stoy et al., 2006a). At PP, $G_{c, G S}$ was reduced due to low $g_{s}$ during drought and low LAI following a severe ice storm event in December 2002 (McCarthy et al., 2006; Stoy et al., 2006a). Oren \& Pataki (2001) and Pataki \& Oren (2003) demonstrated that most species at HW are drought tolerant; only Liriodendron tulipifera decreased $G_{\mathrm{c}}$ with declining $\theta$. We add that soil water savings from later leaf-out phenology at $\mathrm{HW}$ resulted in $G_{\mathrm{c}, \mathrm{GS}}$ that was relatively invariant among years (Stoy et al., 2005, 2006a), although access to deeper water sources cannot be entirely dismissed (as noted in the experimental setup). Consequently, the coefficient of variation (CV) of annual $G_{c}$ was 0.13 at $\mathrm{HW}$ compared with 0.29 at OF 
and 0.23 at PP, consistent with Odum's notion of 'increasing protection' as succession progresses.

It is clear that larger canopy investment at PP resulted in longer recovery times (less resilience) from disturbance than at $\mathrm{OF}$ (Figs 1 and 2). Years with large $\mathrm{NEE}_{\mathrm{A}}$ followed years with ideal growing conditions, which resulted in large leaf area indices (McCarthy et al., 2007). The low soil moisture conditions observed late in the growing season in 2001 and 2005 are known to reduce the magnitude of soil respiration $\left(R_{\text {soil }}\right)$ at both PP and HW (Palmroth et al., 2005). Thus, a combination of drought, disturbance, and lagged recovery from ice storm damage were the primary sources of variability in $\mathrm{NEE}_{\mathrm{A}}$ at PP. $\mathrm{NEE}_{\mathrm{A}}$ at $\mathrm{HW}$ was comparatively resilient to the drought and the disturbances encountered over the measurement period.

The result that the hardwood forest (HW) was insensitive to drought compared with the adjacent coniferous forest (PP) contrasts with previous results in Canada and Europe (Kljun et al., 2006; Granier et al., 2007), which have found coniferous forests to be generally less drought sensitive (Baldocchi, 2008). Our results agree instead with flux research, demonstrating that more mature forests are less drought sensitive (Law et al., 2001). Again, the observed ecosystem-level mechanism for the drought resistance at HW is that later leaf-out, coupled with soil water savings from the underlying clay pan, allows $\mathrm{HW}$ to spend less time with low $\theta$ during the growing season compared with PP (Palmroth et al., 2005), despite broad similarities in $\mathrm{ET}_{\mathrm{GS}}$ between the two forested ecosystems (Stoy et al., 2005, 2006a).

The resistance and resilience to disturbance of the study ecosystems may have important implications for ecosystem succession and thus long-term $\mathrm{C}$ flux (Odum, 1969; Moorcroft, 2003). Ecosystem stability, defined here as the tendency of an ecosystem to remain in its current state, can be formally analyzed by exploring whether the ordinary differential equation $\mathrm{d} B$ / $\mathrm{d} t=f(B)$ has multiple equilibria, as well as the stability of these equilibria, where $f(B)$ describes the carbon gains and losses from the autotrophic system. A symptom of instability is a hysteresis curve when ecosystem state via $B$ is plotted against the rate of change in $B$ (i.e. $\mathrm{d} B$ / $\mathrm{d} t$ ) in the phase plane. Hysteresis suggests that forward and backward shifts occur at different critical conditions, thereby signaling possible existence of multiple equilibria with an unstable zone between their basins of attraction (Scheffer et al., 2001). In our context, these state changes correspond to changes in ecosystem structure that signify ecosystem succession.

To simplify this analysis, consider the autotrophic biomass budget equation, given by

$$
\mathrm{d} B / \mathrm{d} t=\mathrm{GPP}-R_{\mathrm{a}}-L,
$$

where $R_{\mathrm{a}}$ is the autotrophic respiration and $L$ represents rate of $C$ losses due to litterfall, exudation, or other factors such as harvesting. Noting that NEE $=\mathrm{GEP}-\mathrm{RE}$ and $\mathrm{RE}=\mathrm{R}_{\mathrm{a}}+\mathrm{R}_{\mathrm{h}}$, where $R_{\mathrm{h}}$ is the heterotrophic respiration, results in

$$
\mathrm{d} B / \mathrm{d} t=\mathrm{GPP}-\left(\mathrm{RE}-R_{\mathrm{h}}\right)-L=\mathrm{NEE}+R_{\mathrm{h}}-L,
$$

and that $\mathrm{d} B / \mathrm{d} t$ would be proportional to NEE if $R_{\mathrm{h}}-L$ is relatively invariant at the annual time scale in comparison to NEE [i.e. treated as an intercept in Eqn (7)].

If $B=B_{\mathrm{a}}+B_{\mathrm{b}}$, where subscripts $a$ and $b$ refer to the above and belowground autotrophic system, respectively, then $B_{\mathrm{a}}$ is proportional to LAI and woody biomass, and $B_{\mathrm{b}}$ is proportional to root biomass, the latter being proportional to the root area index (RAI). Many studies on plant hydraulics support the idea that RAI and LAI may not be independent for a given rooting zone depth (Jackson et al., 2000), nutrient input (Ewers et al., 2000), or soil texture (Sperry et al., 1998, Hacke et al., 2000). For example, Sperry et al. (1998) used a model based on Darcy's law for hydraulic conductance to show that the ratio of root area to leaf area should fall within limits to avoid plant cavitation, and that this ratio varies as a function of soil properties. If so, $B$ may be proportional to LAI. Hence, only for the purposes of exploring hysteresis in the phase plane at a given site rather than proposing a prognostic model - we can assume that $B$ is proportional to LAI, and that $\mathrm{d} B / \mathrm{d} t$ is proportional to NEE at the annual and growing season time steps. We can then explore a surrogate phase plane for ecosystem stability by plotting $\langle\mathrm{LAI}\rangle_{\mathrm{A}}$ and $\langle\mathrm{LAI}\rangle_{\mathrm{GS}}$ vs. $\mathrm{NEE}_{\mathrm{A}}$ and $\mathrm{NEE}_{\mathrm{GS}}$, respectively (Fig. 8).

A large hysteresis in the phase space is evident for $\mathrm{OF}$ and PP, and a smaller hysteresis was observed at $\mathrm{HW}$ at both annual and growing season time scales (Fig. 8). For $\mathrm{OF}$, the hydro-climatic fluctuations produced large variations in $\langle\mathrm{LAI}\rangle$ and induced a sign shift in $\mathrm{NEE}_{\mathrm{A}}$, but had a minor impact on the magnitude of $\mathrm{NEE}_{\mathrm{A}}$ when compared with PP. The converse is true for PP; changes in $\langle\mathrm{LAI}\rangle$ were relatively small compared with $\mathrm{OF}$, but $\mathrm{NEE}_{\mathrm{A}}$ showed large variability in response to these changes. HW showed small responses in $\langle\mathrm{LAI}\rangle$ and $\mathrm{NEE}_{\mathrm{A}}$ compared with the early successional ecosystems. This analysis suggests that earlier successional stages - represented by OF and PP - are relatively 'unstable' and hence less resistant to disturbances. The instability of these two ecosystems seems to originate from different attributes with potentially similar consequences: (1) the instability in OF (mainly along the abscissa) will directly allow other types of vegetation to invade during times in which LAI is low and can only recover slowly. (2) The instability in PP (mainly along the ordinate) is a consequence of loss of vigor in $C$ accumulation $(\mathrm{d} B / \mathrm{d} t)$, with an indirect effect on stand 

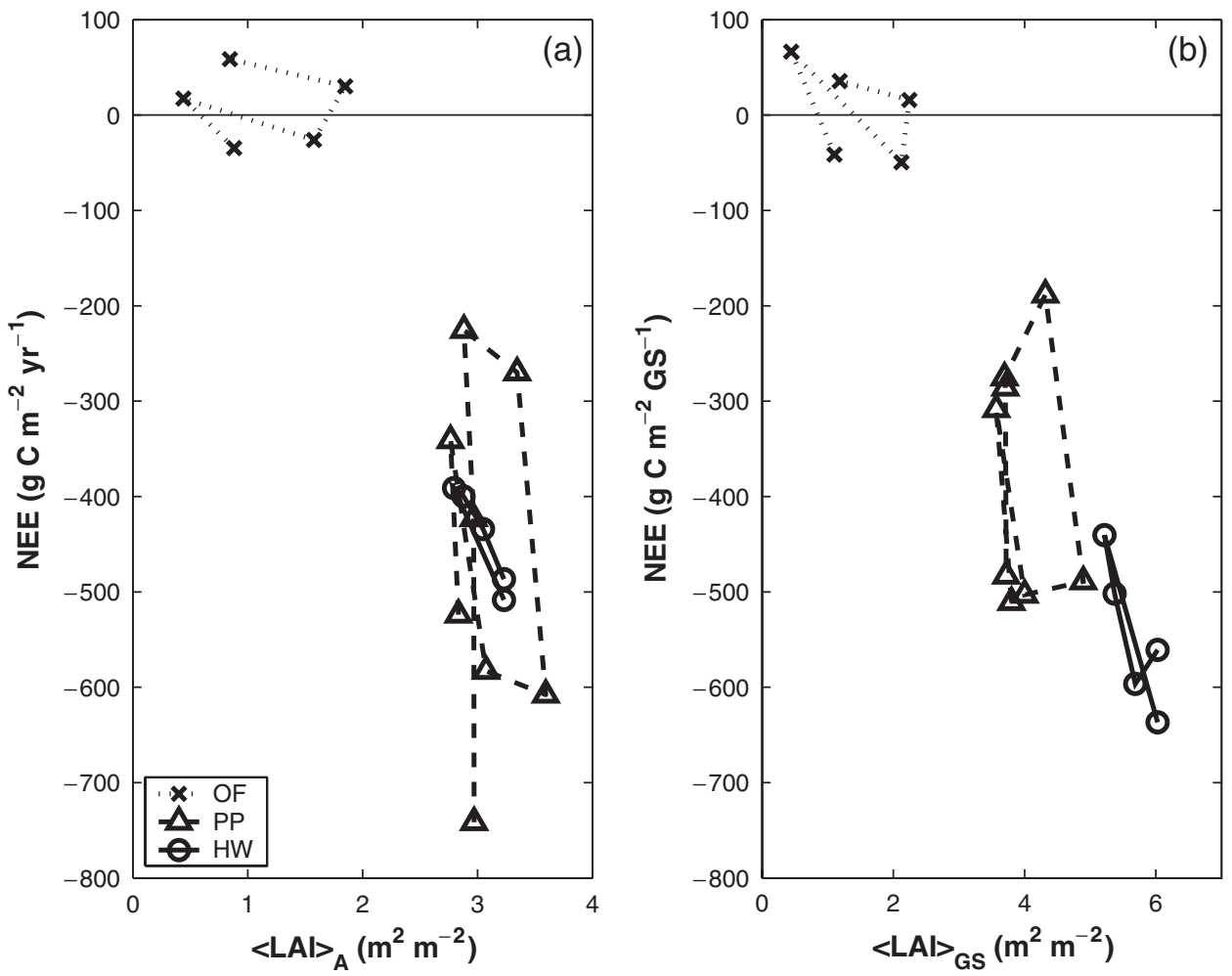

Fig. 8 (a) Phase-space plot of annual net ecosystem exchange $\left(\mathrm{NEE}_{\mathrm{A}}\right)$ as surrogate for the change in ecosystem biomass over time (dB/ $\mathrm{d} t$ ) vs. mean annual LAI ( $\langle\mathrm{LAI}\rangle_{\mathrm{A}}$, as surrogate for $B$ ) for the old-field (OF), planted pine (PP), and hardwood forest (HW) ecosystems in the Duke Forest, NC. (b) Same as part (a), but over the April-September peak growing season (GS) time scale.

vegetation dynamics. The drought and ice storm reduced overstory pine LAI (McCarthy et al., 2006, 2007) and resulted in a decrease in $\mathrm{NEE}_{\mathrm{A}}$ (Figs 1 and 2). This loss of overstory LAI appeared to benefit the growth of understory hardwood species, which will eventually dominate this forest as it follows the typical successional trajectory (Oosting, 1942; Johnston \& Odum, 1956). The minor response of the HW state and rate variables in this simplified analysis indicates that only a major disturbance, for example from a long series of consecutive dry years or via a stand-replacing disturbance such as a hurricane, could push the forest into a new state. Thus, classic ecological theories of succession can be related to modern ideas of ecological resistance and resilience via measurements of changes in ecosystem activity and state from flux and canopy leaf area measurements, respectively.

Following this analysis, it is apparent that the timing and rate of recovery from disturbance may determine the degree to which forest tree species succeed in colonizing OF. A disturbance that reduces LAI will increase exposure and thus light availability. Woody species may benefit if grass LAI replacement is slow. To further assess resilience to disturbance over short time scales at $\mathrm{OF}$ and its potential consequences for succession, the cumulative sum of NEE for 2 weeks before the annual harvest at OF vs. the cumulative sum of NEE for 3 weeks afterwards is plotted (Fig. 9), noting that LAI estimates immediately after the mow were not available for all measurement years. To simplify this analysis, only 2 years with similar early-season harvest dates but different hydrologic regimes, namely 2002 and 2004 (Table 2), are considered.

The response of NEE at OF to harvesting corresponded to hydrological conditions and plant growth before the harvest. The diurnal signal of NEE was notably absent after the 2002 harvest, which coincided with severe drought (Table 2, Fig. 9). It is clear that ecosystem function at $\mathrm{OF}$ did not readily recover from the combination of drought and harvest. In 2004, an optimal year for grass growth, the harvest had minimal impacts on daily NEE, and OF was a net $C$ sink immediately after the mow. It is envisioned that tree recruitment is hindered by the rapidly re-growing grass canopy under this scenario, noting also the effects of mowing on seedling recruitment, and this hypothesis can be further tested using a combination of flux and canopy measurements at $\mathrm{OF}$. 


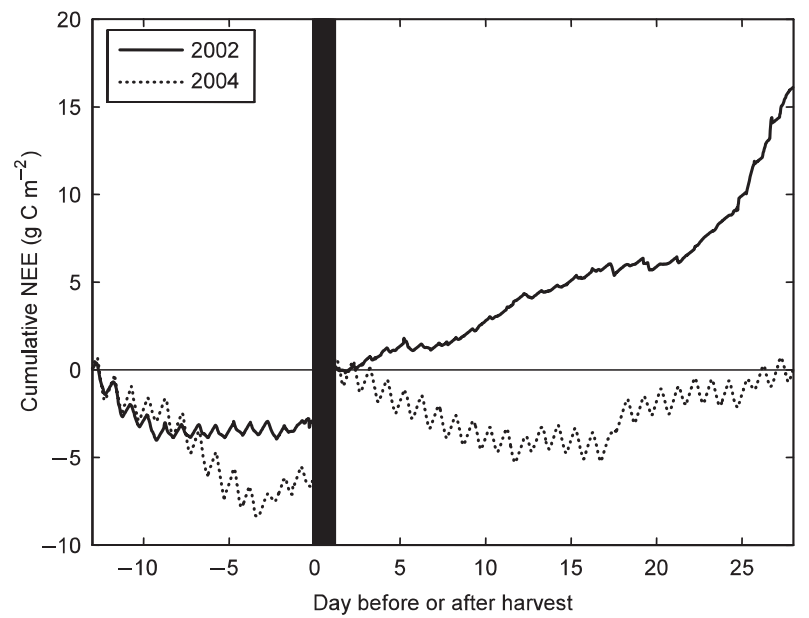

Fig. 9 Cumulative net ecosystem exchange of carbon (NEE) at the old-field ecosystem (OF) for 2 weeks before and 4 weeks after harvesting for the 2002 and 2004 harvests. The vertical bar denotes the day of harvest and is removed from the data record. Dates of harvesting are listed in Table 2.

Table 2 The day of year on which harvesting occurred in the old-field ecosystem (OF), with mean $10-25 \mathrm{~cm}$ soil moisture content and relative hydrologic signature during the time of harvest

\begin{tabular}{llll}
\hline Year & $\begin{array}{l}\text { Day of } \\
\text { harvest }\end{array}$ & $\begin{array}{l}\text { Soil moisture } \\
\left(\mathrm{m}^{3} \mathrm{~m}^{-3}\right)\end{array}$ & $\begin{array}{l}\text { Hydrologic } \\
\text { signature }\end{array}$ \\
\hline 2001 & 179 & 0.25 & Average \\
2002 & 153 & 0.15 & Severe drought \\
2003 & 206 & 0.35 & Wet \\
2004 & 139 & 0.24 & Average \\
2005 & 244 & 0.16 & Severe drought \\
\hline
\end{tabular}

\section{Methodological issues}

It is important to consider the inherent methodological issues that arise when making long-term ecological measurements in a field setting. The hay removed from $\mathrm{OF}$ and used for forage according to local practices (Novick et al., 2004) is likely respired at relatively short time scales off site. The observed NEE should approximate the amount of biomass removed (mean ca. $180 \mathrm{~g} \mathrm{C} \mathrm{m}^{-2} \mathrm{yr}^{-1}$; see Stoy et al., 2006b), if the C balance were to be near zero, the measurements would indicate a source of $\mathrm{C}$ of this magnitude, and a likely candidate is soil C loss. However, OF and PP underwent similar management practices over much of their extent before the establishment of the current vegetation, yet have similar stocks of soil C (ca. $4500 \mathrm{~g} \mathrm{C} \mathrm{m}^{-2}$; K. Johnsen, unpublished data). Stoy et al. (2006b) thus attributed the $\mathrm{C}$ imbalance to a potential bias in the EC measurement system, noting that temporal variability in soil $\mathrm{C}$ over annual time scales can be difficult to discern given its large spatial variability across many ecosystems. A recent review by Baldocchi (2008) demonstrated a positive offset in the relationship between GEP and RE among FluxNet sites that are managed or have been disturbed, including OF. This analysis is consistent with the idea that there is a consistent loss of soil $\mathrm{C}$ from $\mathrm{OF}$ within the error and spatial variability of soil $\mathrm{C}$ measurements such that the EC measurement bias may not exist, lending indirect support to our methodology. We note that the conclusions regarding the experimental hypotheses would not change regardless of whether the EC measurements at OF were biased by ca. $180 \mathrm{~g} \mathrm{C} \mathrm{m}^{-2} \mathrm{yr}^{-1}$, but the relationship in Fig. 4a must be revised to include an offset.

Another methodological concern is the minor edaphic differences among study sites. The belowground environment is heterogeneous both within and among ecosystems, and the dynamic flux footprint incorporates this spatial variability. The depth of the rooting zone and clay pan is inherently patchy, but numerous pit and core measurements confirm that the clay pan is consistently of the order of $30-35 \mathrm{~cm}$ across ecosystems. Despite the core observations, the water balance measurements at HW suggested that the effective rooting depth may be of the order of $50 \mathrm{~cm}$ (Stoy et al., 2006a). Vegetation influences the depth and properties of the soil profile, and it can be expected that more mature ecosystems have greater soil and rooting depth in some cases. This would enhance water availability at HW and may be a factor in the observed resilience NEE to disturbance. However, if drought periods were removed from the analysis, support for the experimental hypotheses would still hold, as PP was also sensitive to ice storm damage. $\mathrm{NEE}_{\mathrm{A}}$ was still more variable at $\mathrm{PP}$ $\left(175 \mathrm{gC} \mathrm{m}^{-2} \mathrm{yr}^{-1}\right)$ than at HW $\left(49 \mathrm{gC} \mathrm{m}^{-2} \mathrm{yr}^{-1}\right)$ when removing 2002 from the analysis, and we see no reason why the ca. 2-year recovery of LAI after the ice storm would have differed had the ice storm not been preceded by drought as the LAI disturbance was large (McCarthy et al., 2007). Interestingly, as mentioned, the years with the highest NEE at both PP and HW were impacted by the mild drought in the late season, in accordance with the chamber observation that $R_{\text {soil }}$ decreases at low $\theta$ (Palmroth et al., 2005).

\section{Management implications}

Active land management in the SE adds a dynamic component to the successional trajectory represented by the three study ecosystems and provides the opportunity to link theoretical and measurement results with land-use practices. Current management trends favor 
the transition of both OF and HW to PP-type ecosystems, which are projected to comprise $30 \%$ of SE forested area by 2040 (Wear \& Greis, 2002). Water (Pataki \& Oren, 2003; Stoy et al., 2006a) and carbon cycling at the ecosystems studied here was similar to other SE ecosystems (Clark et al., 2004; Hanson et al., 2004), as were ecosystem responses to radiation and drought (Wilson et al., 2001; Gholz \& Clark, 2002; Hanson et al., 2004). Our analysis suggests that PP-type ecosystems may not significantly increase regional $\mathrm{C}$ sequestration if they replace HW-type forests, assuming similar future climatic variability. Actively managed PP-type ecosystems are smaller $\mathrm{C}$ pools than mature forests, and may also be smaller $C$ sinks, especially when considering the strong atmospheric $C$ source after clear-cutting (Lai et al., 2002a; Clark et al., 2004), the short rotation length of their management, and their sensitivity to drought and ice storm damage (Oren et al., 1998; McCarthy et al., 2006). The conservation of species-rich hardwood-type forests may be a sensible strategy for maintaining high $C$ sequestration in the $S E$. These forests are already large pools of $C$, and C additions to these pools are less affected by climatic extremes, at least within the semidecadal time scales considered here. Future work should consider the benefits and consequences of converting OF and HW-type ecosystems to PP-type ecosystems on both the terrestrial carbon and water cycles at regional scales (Juang et al., 2007).

\section{Acknowledgements}

This research was supported by the Office of Science (BER), US Department of Energy, Grant No. DE-FG02-95ER82083, by the National Institute of Global Environmental Change (NIGEC) through the Southeast Regional Center at the University of Alabama, Tuscaloosa (DOE cooperative agreement DE-FC030-90ER61010), and by the SERC-NIGEC RCIAP Research Program and the National Science Foundation (NSF-EAR-06-28432 and 06-35787).

We would like to thank F. Colchero, R. B. Jackson, A. Porporato, and B. Poulter for helpful comments on the manuscript, and Y. Parashkevov, J. Edeburn of the office of the Duke Forest, and Brookhaven National Laboratory, for logistical support. All data are available publicly on the AmeriFlux website at public.ornl.gov/ameriflux, the FluxNet website, and Duke FACE website at http://face.env.duke.edu/main.cfm or by request from the first author.

\section{References}

Andrews JA, Harrison KG, Matamala R, Schlesinger WH (1999) Separation of root respiration from total soil respiration using carbon-13 labeling during free-air carbon dioxide enrichment (FACE). Soil Science Society of America Journal, 63, 1429-1435.

Baldocchi DD (2008) 'Breathing' of the terrestrial biosphere: lessons learned from a global network of carbon dioxide flux measurement systems. Australian Journal of Botany, 56, 1-26.
Bosatta E, Ågren GI (1999) Soil organic matter quality interpreted thermodynamically. Soil Biology and Biochemistry, 31, 1889-1891.

Brodribb TJ, Feild TS (2000) Stem hydraulic supply is linked to leaf photosynthetic capacity: evidence from New Caledonian and Tasmanian rainforests. Plant, Cell and Environment, 23, 1381-1388.

Campbell GS, Norman JM (1998) An Introduction to Environmental Biophysics, 2nd edn. Springer, New York.

Carey EV, Sala A, Keane R, Callaway RM (2001) Are old forests underestimated as global carbon sinks? Global Change Biology, 7, 339-344.

Caspersen JP, Pacala SW, Jenkins JC, Hurtt GC, Moorcroft PR, Birdsey RA (2000) Contributions of land-use history to carbon accumulation in US forests. Science, 290, 1148-1151.

Cava D, Giostra U, Siqueira MBS, Katul GG (2004) Organized motion and radiative perturbations in the nocturnal canopy sublayer above an even-aged pine forest. Boundary-Layer Meteorology, 112, 129-157.

Clark KL, Gholz HL, Castro MS (2004) Carbon dynamics along a chronosequence of slash pine plantations in north Florida. Ecological Applications, 14, 1154-1171.

Cowan IR, Farquhar JD (1977) Stomatal function in relation to leaf metabolism and environment: stomatal function in the regulation of gas exchange. In: Symposium of the Society for Experimental Botany (ed. Jennings DH), Cambridge University Press, Cambridge.

Davidson EA, Janssens IA (2006) Temperature sensitivity of soil carbon decomposition and feedbacks to climate. Nature, 440 , 165-173.

Delcourt HR, Harris WF (1980) Carbon budget of the southeastern U.S. biota: analysis of historical change in trend from source to sink. Science, 210, 321-323.

Detto M, Montaldo N, Albertson JD, Mancini M, Katul GG (2006) Soil moisture and vegetation controls on evapotranspiration in a heterogeneous Mediterranean ecosystem on Sardinia, Italy. Water Resources Research, 42, W08419, doi: 10.1029/ 2005WR004693.

Ekblad A, Boström B, Holm A, Comstedt D (2005) Forest soil respiration rate and $\delta^{13} \mathrm{C}$ is regulated by recent above ground weather conditions. Oecologia, 143, 136-142.

Ellsworth DS (1999) $\mathrm{CO}_{2}$ enrichment in a maturing pine forest: are $\mathrm{CO}_{2}$ exchange and water status in the canopy affected? Plant, Cell and Environment, 22, 461-472.

Ewers BE, Oren R, Sperry JS (2000) Influence of nutrient versus water supply on hydraulic architecture and water balance in Pinus taeda. Plant, Cell and Environment, 23, 1055-1066.

Falge E, Baldocchi DD, Olson R et al. (2001) Gap filling strategies for defensible annual sums f net ecosystem exchange. Agricultural and Forest Meteorology, 107, 43-69.

Fan S, Gloor M, Mahlman J, Pacala S, Sarmiento J, Takahashi T, Tans P (1998) A large terrestrial carbon sink in North America implied by atmospheric and oceanic carbon dioxide data and models. Science, 282, 442-446.

Farquhar GD, Lloyd J, Taylor JA et al. (1993) Vegetation effects on the isotope composition of oxygen in atmospheric $\mathrm{CO}_{2}$. Nature, $363,439-443$.

Farquhar GD, von Caemmerer S, Berry JA (1980) A biochemical model of photosynthetic $\mathrm{CO}_{2}$ assimilation in leaves of $\mathrm{C} 3$ species. Planta, 149, 78-90. 
Gholz HL, Clark KL (2002) Energy exchange across a chronosequence of slash pine forests in Florida. Agricultural and Forest Meteorology, 112, 87-102.

Gilmanov TG, Verma SB, Sims PL, Meyers TP, Bradford JA, Burba GG, Suyker AE (2003) Gross primary production and light response parameters of four Southern Plains ecosystems estimated using long-term $\mathrm{CO}_{2}$-flux tower measurements. Global Biogeochemical Cycles, 17, 1071.

Goulden ML, Daube BC, Fan S-M, Sutton DJ, Bazzaz A, Munger JW, Wofsy SA (1997) Physiological responses of a black spruce forest to weather. Journal of Geophysical Research, 102, 28987-28996.

Goulden ML, Munger JW, Fan S-M, Daube BC, Wofsy SC (1996) Measurements of carbon sequestration by long-term eddy covariance: methods and a critical evaluation of accuracy. Global Change Biology, 2, 169-182.

Granier A, Reichstein M, Bréda N et al. (2007) Evidence for soil water control on carbon and water dynamics in European forests during the extremely dry year: 2003. Agricultural and Forest Meteorology, 143, 123-145.

Gu LH, Baldocchi D, Verma SB, Black TA, Vesala T, Falge EM, Dowty PR (2002) Advantages of diffuse radiation for terrestrial ecosystem productivity. Journal of Geophysical Research Atmospheres, 107, doi: 10.1029/2001JD001242.

Gu LH, Baldocchi DD, Wofsy SC, Munger JW, Michalsky JJ, Urbanski SP, Boden TA (2003) Response of a deciduous forest to the Mount Pinatubo eruption: enhanced photosynthesis. Science, 299, 2035-2038.

Gu LH, Fuentes JD, Shugart HH, Staebler RM, Black TA (1999) Responses of net ecosystem exchanges of carbon dioxide to changes in cloudiness: results from two North American deciduous forests. Journal of Geophysical Research - Atmospheres, 104, 31421-31434.

Hacke UG, Sperry JS, Ewers BE, Schäfer KVR, Oren R, Ellsworth DS (2000) Influence of soil porosity on water use in Pinus taeda. Oecologia, 124, 495-505.

Hamilton JG, De Lucia EH, George K, Naidu SL, Finzi AC, Schlesinger WH (2002) Forest carbon balance under elevated $\mathrm{CO}_{2}$. Oecologia, 131, 250-260.

Hanson PJ, Amthor JS, Wullschleger SD et al. (2004) Oak forest carbon and water simulations: model intercomparisons and evaluations against independent data. Ecological Monographs, 74, 443-489.

Högberg P, Nordgren A, Buchmann N et al. (2001) Large-scale forest girdling shows that current photosynthesis drives soil respiration. Nature, 411, 789-792.

Houghton RA (2000) Interannual variability in the global carbon cycle. Journal of Geophysical Research - Atmospheres, 105, 2012120130.

Hsieh CI, Katul G, Chi T (2000) An approximate analytical model for footprint estimation of scalar fluxes in thermally stratified atmospheric flows. Advances in Water Resources, 23, 765-772.

Jackson RB, Banner JL, Jobbagy EG, Pockman WT, Wall DH (2002) Ecosystem carbon loss with woody plant invasion of grasslands. Nature, 418, 623-626.

Jackson RB, Sperry JS, Dawson TE (2000) Root water uptake and transport: using physiological processes in global predictions. Trends in Plant Science, 5, 482-488.
Jaksic V, Kiely G, Albertson J, Oren R, Katul G, Leahy P, Byrne K (2006) Net ecosystem exchange of grassland in contrasting wet and dry years. Agricultural and Forest Meteorology, 139, 323-334.

Janssens IA, Lankreijer H, Matteucci G et al. (2001) Productivity overshadows temperature in determining soil and ecosystem respiration across European forests. Global Change Biology, 7, 269-278.

Johnston DW, Odum EP (1956) Breeding bird populations in relation to plant succession on the Piedmont of Georgia. Ecology, 37, 50-62.

Juang J-Y, Katul GG, Siqueira MBS et al. (2006) Modeling nighttime ecosystem respiration from measured $\mathrm{CO}_{2}$ concentration and air temperature profiles using inverse methods. Journal of Geophysical Research - Atmospheres, 111, D08S05, doi: 10.1029/ 2005JD005976.

Juang J-Y, Porporato A, Stoy PC et al. (2007) Hydrologic and atmospheric controls on convective precipitation events in a southeaster US mosaic landscape. Water Resources Research, 43, W03421, doi: 10.1029/2006WR004954.

Katul GG, Ellsworth DS, Lai CT (2000) Modeling assimilation and intercellular $\mathrm{CO}_{2}$ from measured conductance: a synthesis of approaches. Plant, Cell and Environment, 23, 1313-1328.

Katul GG, Lai C-T, Schäfer KVR, Vidakovic B, Albertson JD, Ellsworth DS, Oren R (2001) Multiscale analysis of vegetation surface fluxes: from seconds to years. Advances in Water Resources, 24, 1119-1132.

Katul GG, Leuning R, Oren R (2003) Relationship between plant hydraulic and biochemical properties derived from a steadystate coupled water and carbon transport model. Plant, Cell and Environment, 26, 339-350.

Keeling CD, Chin JFS, Whorf TP (1996) Increased activity of northern vegetation inferred from atmospheric $\mathrm{CO}_{2}$ measurements. Nature, 382, 146-149.

Kim CP, Entekhabi D (1998) Feedbacks in the land-surface and mixed-layer energy budgets. Boundary-Layer Meteorology, 88, $1-21$.

Kira T, Shidei T (1967) Primary production and turnover of organic matter in different forest ecosystems of the western Pacific. Japanese Journal of Ecology, 17, 70-87.

Kljun N, Black TA, Griffis TJ et al. (2006) Response of net ecosystem productivity of three boreal forest stands to drought. Ecosystems, 9, 1128-1144.

Knohl A, Schulze E-D, Kolle O, Buchmann N (2003) Large carbon uptake by an unmanaged 250-year-old deciduous forest in central Germany. Agricultural and Forest Meteorology, 118, 151-167.

Kull O, Jarvis PG (1995) The role of nitrogen in a simple scheme to scale-up photosynthesis from leaf to canopy. Plant, Cell and Environment, 18, 1174-1182.

Kull O, Kruijt B (1998) Leaf photosynthetic light response: a mechanistic model for scaling photosynthesis to leaves and canopies. Functional Ecology, 12, 767-777.

Kull O, Kruijt B (1999) Acclimation of photosynthesis to light: a mechanistic approach. Functional Ecology, 13, 24-36.

Lai C-T, Katul GG (2000) The dynamic role of root-water uptake in coupling potential to actual transpiration. Advances in Water Resources, 23, 427-439.

Lai C-T, Katul GG, Butnor J et al. (2002a) Modelling the limits on the response of net carbon exchange to fertilization in a southeastern pine forest. Plant, Cell and Environment, 25, 1095-1119. 
Lai C-T, Katul GG, Butnor J, Ellsworth D, Oren R (2002b) Modelling night-time ecosystem respiration by a constrained source optimization method. Global Change Biology, 8, 124-141.

Law BE, Falge E, Gu L et al. (2002) Environmental controls over carbon dioxide and water vapor exchange of terrestrial vegetation. Agricultural and Forest Meteorology, 113, 97-120.

Law BE, Goldstein AH, Anthoni PM et al. (2001) Carbon dioxide and water vapor exchange by young and old ponderosa pine ecosystems during a dry summer. Tree Physiology, 21, 299-308.

Leuning R (1995) A critical appraisal of a combined stomatalphotosynthesis model for C3 plants. Plant, Cell and Environment, 18, 1129-1146.

Lloyd J, Farquhar JD (1994) ${ }^{13} \mathrm{C}$ discrimination during $\mathrm{CO}_{2}$ assimilation by the terrestrial biosphere. Oecologia, 99, 201-215.

Luo YQ, Medlyn BE, Hui DF, Ellsworth D, Reynolds J, Katul GG (2001) Gross primary productivity in Duke Forest: modeling synthesis of $\mathrm{CO}_{2}$ experiment and eddy-flux data. Ecological Applications, 11, 239-252.

McCarthy HR, Oren R, Finzi AC, Ellsworth DS, Kim H-S, Johnsen KH, Millar B (2007) Temporal dynamics and spatial variability in the enhancement of canopy leaf area under elevated atmospheric $\mathrm{CO}_{2}$. Global Change Biology, 13, 2479-2497.

McCarthy HR, Oren R, Kim H-S, Johnsen KH, Maier C, Pritchard SG, Davis MA (2006) Interaction of ice storms and management practices on current carbon sequestration in forests with potential mitigation under future $\mathrm{CO}_{2}$ atmosphere. Journal of Geophysical Research, 111, D15103, doi: 10.1029/2005JD006428.

Moorcroft PR (2003) Recent advances in ecosystem-atmosphere interactions: an ecological perspective. Proceedings of the Royal Society of London Series B - Biological Sciences, 270, 1215-1227.

Morgenstern K, Black TA, Humphreys ER et al. (2004) Sensitivity and uncertainty of the carbon balance of a Pacific Northwest Douglas-fir forest during an El Niño/La Niña cycle. Agricultural and Forest Meteorology, 123, 201-219.

Mortazavi B, Chanton JP, Prater JL, Oishi AC, Oren R, Katul GG (2005) Temporal variability in ${ }^{13} \mathrm{C}$ of respired $\mathrm{CO}_{2}$ in a pine and a hardwood forest subject to similar climatic conditions. Oecologia, 142, 57-69.

Novick KA, Stoy PC, Katul GG, Ellsworth DS, Siqueira MBS, Juang J-Y, Oren R (2004) Carbon dioxide and water vapor exchange in a warm temperate grassland. Oecologia, 138, 259274.

Odum EP (1969) The strategy of ecosystem development. Science, 164, 262-270.

Odum EP (1971) Fundamentals of Ecology. W.B. Saunders, Philadelphia.

Oosting HJ (1942) An ecological analysis of the plant communities of Piedmont, North Carolina. American Midland Naturalist, 28, 1-126.

Oren R, Ellsworth DE, Johnsen KH et al. (2001) Soil fertility limits carbon sequestration by forest-ecosystems in $\mathrm{CO}_{2}$ enriched atmosphere. Nature, 411, 469-472.

Oren R, Ewers BE, Todd P, Phillips N, Katul GG (1998) Water balance delineates the soil layer in which moisture affects canopy conductance. Ecological Applications, 8, 990-1002.

Oren R, Hsieh CI, Stoy PC, Albertson JD, McCarthy HR, Harrell P, Katul GG (2006) Estimating the uncertainty in annual net ecosystem carbon exchange: spatial variation in turbulent fluxes and sampling errors in eddy-covariance measurements. Global Change Biology, 12, 883-896.

Oren R, Pataki D (2001) Transpiration in response to variation in microclimate and soil moisture in southeastern deciduous forests. Oecologia, 127, 549-559.

Oren R, Sperry JS, Katul GG, Pataki DE, Ewers BE, Phillips N, Schäfer KVR (1999) Survey and synthesis of intra- and interspecific variation in stomatal sensitivity to vapor pressure deficit. Plant, Cell and Environment, 22, 1515-1526.

Pacala SW, Hurtt GC, Baker D et al. (2001) Consistent land- and atmosphere-based US carbon sink estimates. Science, 292, 2316-2320.

Palmroth S, Maier CA, McCarthy HR et al. (2005) Contrasting responses to drought of the forest floor $\mathrm{CO}_{2}$ efflux in a loblolly pine plantation and a nearby oak-hickory forest. Global Change Biology, 11, 421-434.

Pataki DE, Oren R (2003) Species differences in stomatal control of water loss at the canopy scale in a mature bottomland deciduous forest. Advances in Water Resources, 26, 1267-1278.

Peters AJ, Ji L, Walter-Shea E (2003) Southeastern US vegetation response to ENSO events (1989-1999). Climatic Change, 60, 175-188.

Potter CS, Klooster SA, Nemani R, Genovese V, Hiatt S, Fladeland M, Gross P (2006) Estimating carbon budgets for U.S. ecosystems. EOS, Transactions, American Geophysical Union, 87, 85-96.

Reichstein M, Papale D, Valentini R et al. (2007) Determinants of terrestrial ecosystem carbon balance inferred from European eddy covariance flux sites. Geophysical Research Letters, 34, L01402, doi: 10.1029/2006GL027780.

Röser C, Montagnani L, Schulze E-D (2002) Net $\mathrm{CO}_{2}$ exchange rates in three different successional stages of the 'Dark Taiga' of central Siberia. Tellus B, 54, 642-654.

Ryan MG, Law BE (2005) Interpreting, measuring, and modeling soil respiration. Biogeochemistry, 73, 3-27.

Sarmiento J, Wofsy S (co-chairs) (1999) A US Carbon Cycle Science Plan: A Report of the Carbon and Climate Working Group. US Global Change Research Program, Washington, DC.

Schäfer KVR, Oren R, Ellsworth DS et al. (2003) Exposure to an enriched $\mathrm{CO}_{2}$ atmosphere alters carbon assimilation and allocation in a pine forest ecosystem. Global Change Biology, 9, 1378-1400.

Schäfer KVR, Oren R, Lai CT, Katul GG (2002) Hydrologic balance in an intact temperate forest ecosystem under ambient and elevated atmospheric $\mathrm{CO}_{2}$ concentration. Global Change Biology, 8, 895-911.

Scheffer M, Carpenter SR, Foley JA, Folke C, Walker BH (2001) Catastrophic shifts in ecosystems. Nature, 413, 591-596.

Schlesinger WH (1997) Biogeochemistry: An Analysis of Global Change, 2nd edn. Academic Press, San Diego.

Siqueira MBS, Katul GG, Sampson DA, Stoy PC, Juang J-Y, McCarthy HR, Oren R (2006) Multi-scale model inter-comparisons of $\mathrm{CO}_{2}$ and $\mathrm{H}_{2} \mathrm{O}$ exchange rates in a maturing southeastern U.S. pine forest. Global Change Biology, 12, 1189-1207.

Sperry JS, Adler FR, Campbell GS, Comstock JP (1998) Limitation of plant water use by rhyizosphere and xylem conduc- 
tance: results from a model. Plant, Cell and Environment, 21, 347-359.

Stoy PC, Katul GG, Siqueira MBS et al. (2005) Variability in net ecosystem exchange from hourly to inter-annual time scales at adjacent pine and hardwood forests: a wavelet analysis. Tree Physiology, 25, 887-902.

Stoy PC, Katul GG, Siqueira MBS et al. (2006a) Separating the effects of climate and vegetation on evapotranspiration along a successional chronosequence in the southeastern U.S. Global Change Biology, 12, 2115-2135.

Stoy PC, Katul GG, Siqueira MBS, Juang J-Y, Novick KA, Oren R (2006b) An evaluation of methods for partitioning eddy covariance-measured net ecosystem exchange into photosynthesis and respiration. Agricultural and Forest Meteorology, 141, 2-18.

Stoy PC, Palmroth S, Oishi AC et al. (2007) Are ecosystem carbon inputs and outputs coupled at short time scales? A case study from adjacent pine and hardwood forests using impulse-response analysis. Plant, Cell and Environment, 30, 700-710.

Taneva L, Pippen JS, Schlesinger WH, Gonzàlez-Meler MA (2006) The turnover of carbon pools contributing to soil $\mathrm{CO}_{2}$ and soil respiration in a temperate forest exposed to elevated $\mathrm{CO}_{2}$ concentration. Global Change Biology, 12, 983-994.
Tang J, Baldocchi D, Xu L (2005) Tree photosynthesis modulates soil respiration on a diurnal time scale. Global Change Biology, 11, 1298-1304.

Urbanski S, Barford C, Wofsy S et al. (2007) Factors controlling $\mathrm{CO}_{2}$ exchange on timescales from hourly to decadal at Harvard Forest. Journal of Geophysical Research, 112, G02020, doi: 10.1029/2006JG000293.

Valentini R, Matteucci G, Dolman AJ et al. (2000) Respiration as the main determinant of carbon balance in European forests. Nature, 404, 861-865.

Wear DN, Greis JG (2002) The southern forest resource assessment summary report. In: Southern Forest Resource Assessment. Gen. Tech. Rep. SRS-53 (eds Wear DN, Greis JG), US Department of Agriculture, Forest Service, Southern Research Station, Asheville, NC.

Wilson KB, Baldocchi DD, Hanson PJ (2001) Leaf age affects the seasonal pattern of photosynthetic capacity and net ecosystem exchange of carbon in a deciduous forest. Plant, Cell and Environment, 24, 571-583.

Wong SC, Dunin FX (1987) Photosynthesis and transpiration of trees in a Eucalypt forest stand: $\mathrm{CO}_{2}$, light and humidity responses. Australian Journal of Plant Physiology, 14, 619-632.

Zhou G, Liu S, Li Z et al. (2006) Old-growth forests can accumulate carbon in soils. Science, 314, 1417. 